\title{
Direito do Consumidor e os Organismos Geneticamente Modificados
}

Helita Barreira Custódio ${ }^{(\star)}$

\section{RESUMO}

Foram examinadas as normas jurídicas internacionais e nacionais, os princípios constitucionais da conciliação do desenvolvimento socioeconômico com a preservação da qualidade ambiental propícia à vida, com a proteção do consumidor e a conservação da saúde pública. Examinou-se, também, a problemática dos organismos geneticamente modificados e o Direito do consumidor no Direito Comparado e no Brasil, para deduzir os deveres e as responsabilidades das pessoas jurídicas de direito público e de direito privado para cumprir, adequar ou atualizar a legislação e fiscalizar a observância das normas sobre o direito do consumidor e sobre as atividades e os projetos que envolvam organismos geneticamente modificados (OGMs) no Território Brasileiro.

\section{Descritores}

Organismos Geneticamente Modificados (OGMs); Direito Ambiental; Proteção à Saúde; Direito do Consumidor; Direito Sanitário.

\section{ABSTRACT \\ The international and national law had been examined, the constitutio- nal principles of the conciliation of socio-economic development with the \\ (“) Doutora em Direito e Professora "Livre-Docente” pela Universidade de São Paulo (tese: Respon- sabilidade Civil por Danos ao Meio Ambiente); Aperfeiçoamento em Administração Pública, com especialização em Direito Urbanístico, pela Universidade de Roma "LA SAPIENZA". Av. Brig. Luis Antonio, 733, São Paulo. Entrada: 1.3.2003. Aprovado em 26.6.2003.}


preservation of environmental quality propitious to the life, with the protection of the consumer and the conservation of the public health. It was examined, also, the problematic one of the genetic modified organisms and consumers rights in the Comparative Law and in Brazil, to deduce the duties and the responsibilities of public and private persons, to adjust or to update the legislation and to verify the compliance of the norms on consumers rights and the activities and the projects that involve genetic modified organisms (GMOs) in the Brazilian Territory.

\section{Key-words}

Genetic Modified Organisms (GMOs); Environmental law; Health Protection; Consumers Rights; Health Law.

Diante da progressiva relevância das novas exigências sociais, é sempre oportuno recordar que o Direito, como um conjunto de princípios e normas obrigatórios de conduta social, impostos pelo Poder Público competente, mediante sanção, para a ordem e o equilíbrio de interesses na própria sociedade, tem como finalidade fundamental "servir a vida, regular a vida". Assim, a "ratio juris é uma força viva e móvel que anima os dispositivos e os acompanha no seu desenvolvimento" ${ }^{(1)}$. Neste sentido, o Direito, considerado como indispensável "conjunto de regras de conduta", tem um "preciso fim fundamental: aquele de assegurar a pacífica convivência" de ordem social, sempre a serviço da vida saudável. Tal "pacífica convivência somente será possível mediante a realização de dois objetivos essenciais: aquele da certeza do direito e aquele da certeza da observância do próprio direito"(2). O Direito objetivo ou norma agendi, classificado como direito público e direito privado, quer no âmbito nacional, quer nos âmbitos comparado, comunitário e internacional, com força coercitiva em qualquer de suas manifestações, revela-se, incontestavelmente, um fenômeno de ordem social, um princípio ou uma norma antes de tudo de caráter geral e abstrato, por imposição da sociedade, no interesse da própria sociedade. Nesse sentido, dentre os princípios e as normas jurídicas aplicáveis ao direito do consumidor e aos organismos geneticamente modificados, previstos em nosso Sistema Jurídico, destacam-se:

\section{NORMAS JURIDICAS INTERNACIONAIS}

Partindo da Declaração do Rio/92, que reafirma a Declaração de Estocolmo/72, demonstram-se, dentre os princípios aplicáveis, aqueles segun-

(1) Maximiliano, Carlos. Hermenêutica e Aplicação do Direito. 9a ed., Rio de Janeiro: Forense, 1979, pp. 153-154.

(2) Barile, Paolo. Istituzione di diritto pubblico. 2. ed., CEDAM, Padova, 1975, p. 3; Beviláqua, Clóvis. Teoria Geral do Direito Civil. 7. ed., Francisco Alves, SP-RJ-BH, 1955, p. 11; Ruggiero, Roberto de. Instituições de Direito Civil, v. I, 3. ed., trad. do orig. italiano por Ary dos Santos, São Paulo: Saraiva, 1971 , p. 15 e segs. 
do os quais: "Os Estados devem cooperar, em espírito de parceria global, para conservar, proteger e restabelecer a saúde e a integridade do ecossistema Terra" (princ. 7); "Os Estados devem facilitar e estimular a conscientização e participação pública, tornando as informações amplamente disponíveis" (princ. 10), bem como "estabelecer legislação ambiental efetiva" (princ. 11). Reafirmando o princípio da prevenção ou da precaução no sentido de evitar, reduzir ou eliminar efetivamente efeitos prejudiciais para o meio ambiente, estabelece a citada Declaração que: "Onde houver ameaças de danos sérios e irreversíveis, a falta de plena certeza científica não deve ser usada como razão para adiar medidas economicamente viáveis para impedir a degradação ambiental" (princ. 15); acrescenta que: "A avaliação de impacto ambiental, como instrumento nacional, deve ser empreendida para atividades planejadas que tenham probabilidade de causar significativo impacto e estejam sujeitas a uma decisão da autoridade nacional competente" (princ. 16). Como princípio harmônico e complementar, determina: "A paz, o desenvolvimento e a proteção ambiental são interdependentes e indivisíveis" (princ. 25).

O Código Internacional de Conduta para a Distribuição e Utilização de Praguicidas (agrotóxicos), aprovado pela Resolução n. 10/85 da Conferência Mundial da FAO, considerando, dentre outros motivos, que o aumento da utilização de praguicidas impõe, paralelamente, intensos esforços necessários para introduzir sistemas de controle biológico e integrado das pragas, que os praguicidas podem ser perigosos para os seres humanos e 0 meio ambiente e que todos os interessados, governos, fabricantes, comerciantes e usuários, "devem adotar medidas imediatas para eliminar riscos desnecessários", não só no país de origem mas também nos países que importam tais produtos perigosos, com os objetivos de declarar as responsabilidades e estabelecer normas de conduta para todas as entidades públicas e privadas, institui, dentre outras regras de caráter preventivo, aquelas sobre "manejo e ensaio de praguicidas" (arts. 3, 4); "Redução dos perigos para a saúde" (art. 5); "Requisitos regulamentares e técnicos" (art. 6); "Distribuição e comércio" (art. 8); "Intercâmbio de informação" (art. 9); "Etiqueta" (rótulos) de forma clara (art. 10); "Publicidade", notadamente sobre a segurança do produto, sua natureza, composição, adequação ao uso, ao reconhecimento, à aprovação oficial (art. 11), tudo visando ao uso seguro dos praguicidas, no interesse do meio ambiente saudável, da saúde pública e do bemestar de todos (FAO, Código Internacional de Conduta para la Distribución y Utilización de Plaguicidas, Roma, 1986).

O "Codex Alimentarius Comission", no âmbito da competência da FAO e da OMS, considerando os múltiplos aspectos da produção alimentar, desde as garantias sanitárias aos protocolos científicos e comerciais, tem como fim fixar parâmetros ou padrões precisos relacionados com a presença de microorganismos ou com os resíduos de agrotóxicos e as medidas preventivas referentes à avaliação de risco, visando à segurança alimentar. 
Para salva-guardar os consumidores, o citado Código seleciona e fixa as regras gerais para a etiquetagem ou rotulagem e a confecção dos produtos, de forma compatível com as normas internacionais de higiene alimentar no sentido de garantir a qualidade do alimento do ponto de vista sanitário. $O$ Código se resume numa infinidade de normas e parâmetros em 16 volumes, atualizados de dois em dois anos por comissões nacionais e regionais, cujos trabalhos sobre temas específicos referentes a alimentos são submetidos à apreciação da Sessão Plenária composta de 500 delegados dos 163 Países representantes de organizações internacionais, governamentais e não-governamentais, incluídas as associações de consumidores que, apesar de não terem direito a voto, podem apresentar suas propostas. No tocante aos alimentos transgênicos, trata-se de assunto palpitante das mais recentes reuniões plenárias na sede da FAO, em Roma. Neste sentido, evidencia-se que o CODEX, de forma cautelosa, estabelece normas visando a garantir "uma gestão equilibrada e imparcial do problema", salientando-se, dentre os mais espinhosos argumentos, aquele da "etiquetagem" nos alimentos transgênicos, já em andamento uma ampla discussão sobre o complexo e polêmico assunto. Além da segurança e da nutrição inerentes aos alimentos transgênicos, há outros preocupantes problemas, como a necessidade do desenvolvimento sustentável, a proteção da biodiversidade e o impacto que as biotecnologias podem ter sobre o terceiro mundo, inquietantemente diante de grandes interesses econômicos em jogo. Como medidas conciliatórias, salienta-se que representantes da FAO e da OMS já começaram a trabalhar em conjunto com organismos internacionais como a Organização Mundial para o Comércio-WTO'(3).

A Agenda 21, estabelecendo diretrizes para manejo ambientalmente saudável da Biotecnologia, adota princípios internacionalmente sensatos no sentido de promover o desenvolvimento de suas aplicações sustentáveis e "conquistar a confiança do público", mediante atividades em áreas de programas com objetivos de: "Aumento da disponibilidade de alimento, ..."; "Melhoria da saúde humana"; "Aumento da proteção do meio ambiente"; "Aumento da segurança e do desenvolvimento de mecanismos de cooperação internacional" (Cap. 16, introdução). De forma preventiva, observam-se diretrizes sobre a identificação prévia, antes da modificação, dos "impactos socioeconômicos, culturais e ambientais das modificações", bem como "a necessidade de promover o desenvolvimento social e econômico sustentável, com especial atenção para a forma como o uso da biotecnologia irá incidir sobre a manutenção da integridade ambiental" (Cap. 16.4). Além do prévio estudo de impacto ambiental, evidenciam-se diretrizes preventivas sobre a "manutenção e desenvolvimento de bancos de dados com informa-

(3) Bussolati, Mariella e Morandi, Sabina. II gene nel piato cit., Gli Ogm Nelle Leggi (os organismos geneticamente modificados nas leis) - La normativa nazionale e internazionale - II Codex Alimentarius, p. 101 e segs. Aos interessados em obter informações ou publicações sobre o Codex Alimentarius Commission: http://www.fao.org/librar; publications-sales@fao.org. 
ções sobre os impactos de organismos sobre o meio ambiente e a saúde, com objetivo de facilitar a avaliação dos riscos" (Cap. 16.6). Conclui-se que o objetivo da melhoria da proteção do meio ambiente "é prevenir, deter e reverter o processo de degradação ambiental por meio do uso adequado da biotecnologia, juntamente com outras tecnologias", no interesse da saúde, do meio ambiente saudável, sempre levando em conta as considerações éticas, em todos os âmbitos de Governo ou entidades responsáveis pelo manejo ambientalmente saudável da biotecnologia.

A Convenção sobre a Diversidade Biológica, assinada no Rio de Janeiro em 5.6.1992, aprovada pelo Decreto Legislativo n. 2, de 3.2.1994, em vigor, no Brasil, em 29.5.1994 e promulgada pelo Decreto n. 2.519, de 16.3.1998, considerando, dentre outras convincentes justificativas: o valor intrínseco da diversidade biológica e dos valores ecológico, genético, social, econômico, científico, sanitário, educacional, cultural, recreativo e estético ou paisagístico da diversidade biológica e de seus componentes; a importância da diversidade biológica para a evolução e para a manutenção dos sistemas necessários à vida da biosfera; que a conservação da diversidade biológica é uma preocupação comum à humanidade; que os Estados têm direitos soberanos sobre os seus próprios recursos biológicos e são responsáveis pela conservação de sua diversidade biológica e pela utilização sustentável de seus recursos biológicos; que a falta geral de informação e de conhecimento sobre a diversidade biológica impõe a necessidade urgente de desenvolver capacitação científica, técnica e institucional ao planejamento e execução de medidas adequadas; que é vital prever, prevenir e combater na origem as causas da sensível redução da diversidade biológica; que, quando exista ameaça de sensível redução ou perda da diversidade biológica, a falta de plena certeza científica não deve ser usada como razão para postergar medidas para evitar ou minimizar essa ameaça; que a conservação e a utilização sustentável da diversidade biológica são de importância absoluta para atender às necessidades de alimentação, de saúde e de outra natureza da crescente população mundial, para o que são essenciais o acesso e a repartição de recursos genéticos e tecnologia; a necessidade de conservar e utilizar, de forma sustentável, a diversidade biológica para benefício das gerações presentes e futuras, consagra os princípios: da "Utilização Sustentável de Componentes da Diversidade Biológica", ou da conciliação do desenvolvimento socioeconômico com a preservação do meio ambiente (art. 10); da Educação e Conscientização Pública, visando à conservação e à utilização sustentável da diversidade biológica, bem como da Prevenção de Danos Ambientais, todos vinculados ao relevante instrumento da Avaliação de Impacto e Minimização de Impactos Negativos, exigindo-se "a avaliação de impacto ambiental", de projetos propostos, "a fim de evitar ou minimizar sensíveis efeitos negativos na diversidade biológica", com a participação pública (arts. 12, 13, 14). 


\section{NORMAS JURIDICAS NACIONAIS: CONSTITUCIONAIS, LEGAIS E REGULAMENTARES}

De forma harmônica com as normas internacionais aprovadas pelo Governo brasileiro, partindo da Constituição, dentre as normas fundamentais aplicáveis ao tema em exposição, destacam-se: Tratando dos Direitos e Garantias Fundamentais, estabelece a Magna Carta que todos são iguais perante a lei, garantindo-se a inviolabilidade do direito à vida, à liberdade, à igualdade, à segurança, à propriedade (CF, art. $\left.5^{\circ}\right)$, nos termos seguintes: "O Estado promoverá, na forma da lei, a defesa do consumidor" (CF, art. 5, XXXII); "todos têm direito a receber dos órgãos públicos informações de seu interesse particular, ou de interesse coletivo ou geral, que serão prestadas no prazo da lei" (art. 5o, XXXIII); "são a todos assegurados, independentemente do pagamento de taxas: o direito de petição aos poderes públicos em defesa de direitos ou contra ilegalidade ou abuso do poder; a obtenção de certidões em repartições públicas, para defesa de direitos e esclarecimentos de situações de interesse pessoal" (art. 5ํ, XXXIV).

No tocante aos Princípios Gerais da Atividade Econômica, determina a Magna Carta que o titular de qualquer atividade econômica observará os princípios, notadamente no presente caso, da "função social da propriedade" (pública e privada); da "livre concorrência" (que não admite qualquer sistema de monopólio ou de restrições ilegais ao exercício de atividade econômica, ressalvados os monopólios da União expressamente definidos nos arts. 21, XXIII, e 177 da CF, atendidos os princípios e as condições ali previstos); da "defesa do consumidor" (em todos os seus aspectos ao seu total bem-estar, como transparentes informações sobre o produto posto à sua disposição, a segurança alimentar, a saúde pública); da "defesa do meio ambiente" (com todos os seus componentes); da "redução das desigualdades regionais e sociais" (é assegurado a todos o livre exercício de qualquer atividade econômica em qualquer parte do território nacional); do "tratamento favorecido para as empresas de pequeno porte constituídas sob as leis brasileiras e que tenham sua sede e administração no País" (que não admite qualquer forma de discriminação ou marginalização em favor de grandes empresas nacionais e multinacionais) (CF, art. 170, III, IV, V, VI, VII, IX). No âmbito da Política Agrícola, no caso da propriedade rural, por força da norma constitucional, o princípio de sua função social é cumprido quando tal propriedade atende, simultaneamente, além de outros critérios e graus de exigência estabelecidos em lei, os requisitos, notadamente, do "aproveitamento racional e adequado", da "utilização adequada dos recursos naturais disponíveis e preservação do meio ambiente", tudo mediante planejamento e execução na forma da Constituição e da lei (CF, arts. 186, I, II, 187).

No âmbito da Ordem Social, determina a Constituição que a saúde é direito de todos e dever do Estado, garantido mediante políticas sociais e econômicas que visem à redução do risco de doença e de outros agravos, 
bem como ao acesso universal e igualitário às ações e serviços para a sua promoção, proteção, recuperação e conservação. Neste sentido, são considerados de relevância as ações e os serviços públicos de saúde, cabendo ao Poder Público dispor, nos termos da lei, sobre sua regulamentação, seu planejamento, fiscalização e controle, devendo sua execução ser feita diretamente ou através de terceiros (pessoa física ou jurídica de direito privado). Dentre outras atribuições relevantes, destacam-se: "fiscalizar e inspecionar alimentos, compreendido o controle de seu teor nutricional, bem como bebidas e águas para consumo humano"; "participar do controle e fiscalização da produção, transporte, guarda e utilização de substâncias e produtos psicoativos, tóxicos e radioativos"; "colaborar na proteção do meio ambiente, nele compreendido o do trabalho" (CF, arts. 196, 197, 198, 200, VI, VII, VIII).

De forma harmônica e integrada com os princípios e as normas constitucionais citados, a vigente Magna Carta, inovatoriamente, consagra um Capítulo especial referente à proteção do meio ambiente saudável como direito de todos. Assim: todos têm direito ao meio ambiente ecologicamente equilibrado, bem de uso comum do povo e essencial à sadia qualidade de vida, impondo-se ao Poder Público (União, Estados, Distrito Federal e Municípios, com as respectivas entidades da administração pública indireta) e à coletividade (todas as pessoas físicas ou jurídicas de direito privado, com ou sem fins lucrativos) o dever de defendê-lo e preservá-lo para as presentes e futuras gerações (CF, art. 225). Para assegurar a efetiva aplicação deste fundamental direito ao meio ambiente saudável, no legítimo interesse de todos, compete ao Poder Público, dentre outras atribuições: preservar e restaurar os processos ecológicos essenciais, bem como prover o manejo ecológico das espécies e dos ecossistemas (CF, art. 225, § 1, I); preservar a diversidade e a integridade do patrimônio genético do País, bem como fiscalizar as entidades dedicadas à pesquisa e manipulação de material genético $\left(\S 1^{\circ}, \mathrm{II}\right)$; definir, em todas as Unidades da Federação, espaços territoriais e seus componentes a serem especialmente protegidos, vedada qualquer utilização que comprometa a integridade dos atributos que justifiquem sua proteção ( $\S 1^{\circ}$, III); exigir, na forma da lei, estudo prévio de impacto ambiental, a que se dará publicidade, para instalação de obra ou atividade potencialmente degradadora do meio ambiente $\left(\S 1^{\circ}, \mathrm{IV}\right)$; controlar a produção, a comercialização e o emprego de técnicas, métodos e substâncias que comportem riscos para a vida, a qualidade de vida e o meio ambiente ( $\S$ $\left.1^{\circ}, \mathrm{V}\right)$; promover a educação ambiental em todos os níveis de ensino e a conscientização pública para a preservação do meio ambiente $\left(\S 1^{\circ}, \mathrm{VI}\right)$; proteger a fauna e a flora, vedadas, na forma da lei, as práticas que coloquem em risco sua função ecológica, provoquem a extinção de espécies ou submetam os animais a crueldade ( $\left.\S 1^{\circ}, \mathrm{VII}\right)$.

De forma vinculada às citadas normas constitucionais vigentes, a Constituição Federal, além de definir as competências privativas e suplementares das Unidades da Federação em matéria de interesse dos res- 
pectivos territórios, como, dentre outras, a ambiental, a da segurança alimentar, da saúde pública, estabelece expressamente a competência concorrente legislativa e a competência comum executiva da União, dos Estados, do Distrito Federal e dos Municípios.

No caso da competência concorrente da União, dos Estados (incluída implicitamente a dos Municípios integrantes dos Estados e dos Territórios em matérias específicas de interesse local e de forma compatível com as normas gerais da lei federal ou estadual correspondente) e do Distrito Federal, trata-se de competência para legislar concorrentemente sobre, dentre outras matérias: produção e consumo, proteção do meio ambiente, das florestas, da flora e fauna; conservação da natureza, do patrimônio turístico e paisagístico; proteção e defesa da saúde; defesa do solo e dos recursos naturais; controle da poluição; responsabilidade por dano ao meio ambiente, ao consumidor, a bens e direitos de valores integrantes do patrimônio cultural; garantia de acesso a todos ao efetivo exercício dos direitos educacionais, culturais, científicos, tecnológicos, no legítimo interesse público, de acordo com as respectivas peculiaridades, observadas as normas gerais de competência da União ou dos Estados (destes na falta das normas gerais da União e compatíveis com as da lei federal superveniente) (CF, art. $24, \mathrm{~V}, \mathrm{VI}, \mathrm{VII}, \mathrm{VIII}, \mathrm{IX}, \mathrm{XII}, \S \S 2^{\circ}, 3^{\circ}, 4^{\circ}, \mathrm{c} / \mathrm{c}$ arts. 18, 25, 30, 170, III, IV, V, VI; 185, 186, 187; 196 a 200; 218; 225).

No tocante à competência comum da União, dos Estados, do Distrito Federal e dos Municípios, trata-se de competência sobre assunto de interesse comum das Unidades da Federação, em igualdade de condições, de forma compatível com o princípio da independência e harmonia dos Poderes Públicos entre si, em cooperação recíproca e sintonia, sem superposições e paralelismos, sem interferências nas respectivas competências constitucionais, no legítimo interesse de todos. Como atribuições de natureza executiva, sem prejuízo da competência legislativa privativa, concorrente ou suplementar de cada Unidade Federada sobre assunto de interesse do respectivo território, evidenciam-se, dentre outras funções de competência comum diretamente relacionadas com a proteção do patrimônio ambiental e da saúde pública, as seguintes: zelar pela guarda (vigilância, respeito, observância, fortalecimento) da Constituição, das leis e das instituições democráticas e conservar o patrimônio público (nos âmbitos nacional, estadual, distrital e municipal); cuidar da saúde e da assistência pública (a proteção da sadia qualidade de vida interessa à saúde de todos); proporcionar os meios de acesso à cultura, à educação e à ciência; proteger o meio ambiente e combater a poluição em qualquer de suas formas; preservar as florestas, a fauna e flora, fomentar a produção agrícola e organizar o abastecimento alimentar (CF, art. 23, I, II, V, VI, VII, VIII, X, c/c arts. 170, III, IV, V, VI, VII, IX; 185 a 187; 196 a 200; 216; 218; 225).

Quanto às Normas Legais e Regulamentares, dentre os básicos textos contendo princípios e regras interdependentes e aplicáveis ao relevante 
tema em exposição, destacam-se os seguintes: a) Política Ambiental: A Lei geral n. 6.938, de 31.8.1981, dispõe sobre a Política Nacional do Meio Ambiente, seus objetivos, seus mecanismos e instrumentos básicos à defesa, à recuperação, à melhoria e à preservação da qualidade ambiental propícia à vida, regulamentada pelo Decreto n. 99.274, de 6.6.1990, e pelos demais regulamentos posteriores (com as alterações e complementações ajustáveis à CF/88, destacando-se as Leis n. 7.804, de 18.7.1989, n. 9.960, de 28.1.2000, n. 9.985, de 18.7.2000, n. 10.165, de 27.12.2000). b) Política Sanitária: A Lei geral n. 8.080, de 19.9.1990, dispõe sobre as condições para a promoção, proteção, melhoria e recuperação da saúde, como direito fundamental da pessoa humana (com as normas legais e regulamentares anteriores e posteriores à sua vigência). Por força da citada Lei, a saúde tem como fatores determinantes e condicionantes, dentre outros, a alimentação adequada e o controle de seu teor nutricional, o saneamento básico e o meio ambiente saudável, a vigilância sanitária definida como um conjunto de ações capaz de eliminar, diminuir ou prevenir riscos à saúde, de intervir nos problemas sanitários decorrentes da degradação do meio ambiente, da produção ao consumo de bens de interesse da saúde (arts. $3^{\circ}$ e 6을. Dentre as normas sucessivas aplicáveis em defesa da saúde pública, demonstram-se: a Lei n. 8.543, de 23.12.1992, determina a obrigatória impressão de advertência em rótulos e embalagens de alimentos industrializados que contenham glúten, a fim de evitar a doença celíaca; a Lei n. 9.605, de 12.2.1998, dispõe sobre a definição de crimes de poluição em níveis que resultem ou possam resultar danos à saúde pública. c) Política Agrícola: A Lei geral n. 8.171, de 17.1.1991, dispõe sobre a Política Agrícola e estabelece seus fundamentos, seus objetivos, suas competências, suas atividades, suas ações, seus instrumentos referentes às atividades agrícolas e outras atividades interdependentes, relacionadas com a produção, o processamento e a comercialização dos produtos, subprodutos ou derivados. Como atividade econômica vinculada aos princípios constitucionais, a citada Lei define, dentre os objetivos da Política Agrícola: proteger o meio ambiente, garantir o seu uso racional e estimular a recuperação dos recursos naturais; promover a descentralização da execução dos serviços públicos de apoio ao setor rural, visando à complementariedade de ações com Estados, Distrito Federal e Municípios, cabendo a estes assumir suas responsabilidades na execução da Política Agrícola, adequando os diversos instrumentos às suas necessidades e realidades (arts. $\left.1^{\circ}, 2^{\circ}, 3^{\circ}\right)$. Dentre as normas anteriores vinculadas à Política Agrícola, evidenciam-se as da Lei $\mathrm{n}$. 7.802, de 11.7.1989, sobre a Pesquisa, a Experimentação, a Produção, a Embalagem e Rotulagem, o Transporte, o Armazenamento, a Comercialização, a Propaganda Comercial, a Utilização, a Importação, a Exportação, o Destino Final dos Resíduos e embalagens, o Registro, a Classificação, o Controle, a Inspeção e a Fiscalização de Agrotóxicos, Seus Componentes (princípios ativos, produtos técnicos, suas matérias-primas, os ingredientes e aditivos usados na fabricação de agrotóxicos) e Afins (com as altera- 
ções das Leis n. 9.294, de 15.7.1996, n. 9.974, de 6.6.2000, n. 10.167, de 27.12.2000). Como normas posteriores, alterando e complementando a Lei geral sobre a Política Agrícola, destacam-se: As Leis n. 8.174, de 30.1.1991, n. 9.272, de 3.5.1996, n. 9.712, de 20.11.1998, além dos respectivos regulamentos e de grande número de atos normativos correlatos.

Tratando-se dos Direitos do Consumidor, como direitos fundamentais constitucionalmente garantidos (CF, arts. $5^{\circ}, \mathrm{XXXII}, 170, \mathrm{~V}, \mathrm{c} / \mathrm{c}$ art. 24 , VIII e ADCT, art. 48), a Lei n. 8.078, de 11.9.1990 - Código de Defesa do Consumidor, dispondo sobre a proteção do consumidor, define, dentre outros básicos direitos do consumidor: a) a proteção da vida, saúde e segurança contra os riscos provocados por práticas de fornecimento de produtos e serviços considerados perigosos ou nocivos; b) a educação e divulgação sobre o consumo adequado dos produtos e serviços, asseguradas a liberdade de escolha e a igualdade nas contratações; c) a informação adequada e clara sobre os diferentes produtos e serviços, com a especificação correta de quantidade, características, composição, qualidade e preço, bem como sobre os riscos que apresentem; d) a proteção contra a publicidade enganosa e abusiva, métodos comerciais coercitivos ou desleais, bem como contra práticas e cláusulas abusivas ou impostas no fornecimento de produtos e serviços; e) a efetiva prevenção e reparação de danos patrimoniais e morais, individuais, coletivos e difusos, com acesso aos órgãos judiciários e administrativos; f) a adequada e eficaz prestação dos serviços públicos em geral, além de outros direitos nacionais e internacionais decorrentes de tratados ou convenções de que o Brasil seja signatário (arts. 6으, I, II, III, IV, VI, $\left.\mathrm{VII}, \mathrm{X}, 7^{\circ}\right)$. Por força da citada Lei, o fornecedor de produtos e serviços potencialmente nocivos ou perigosos à saúde ou segurança deverá informar, de maneira ostensiva (clara) e adequada, a respeito da sua nocividade ou periculosidade, sem prejuízo da adoção de outras medidas cabíveis em cada caso concreto (art. 9º).

Com estas breves demonstrações, em resumo, trata-se de princípios e normas legais e regulamentares interdependentes, compatíveis, complementares e vinculados tanto aos princípios e às normas da vigente Constituição e dos Atos Internacionais citados e em vigor no Brasil, como aos princípios jurídicos da prevenção ou da precaução de riscos ou danos ambientais e da conciliação ou compatibilização do desenvolvimento socioeconômico com a preservação do meio ambiente saudável e propício à vida, à segurança alimentar, à saúde pública, todos consolidados no Sistema Jurídico Brasileiro, visando à proteção e à defesa, dentre outros, dos direitos do consumidor, individual, coletiva ou publicamente considerado.

No tocante aos Organismos Geneticamente Modificados, como textos aplicáveis, demonstram-se os seguintes: A Lei n. 8.974, de 5.1.1995, regulamentando os incisos $\|$ e V do $\S 1^{\circ}$ do art. 225 da Constituição Federal (com as alterações da Lei n. 9.985, de 18.7.2000), estabelece normas para 
- uso das técnicas de engenharia genética e liberação no meio ambiente de organismos geneticamente modificados, autoriza o Poder Executivo a criar, no âmbito da Presidência da República, a Comissão Técnica Nacional de Biossegurança-CTNBio. Estabelecendo normas de segurança e mecanismos de fiscalização no uso das técnicas de engenharia genética na construção, no cultivo, na manipulação, no transporte, na comercialização, no consumo, na liberação e descarte de organismo geneticamente modificado (OGM), a presente Lei tem como finalidade proteger a vida e a saúde da pessoa humana, dos animais e das plantas, bem como o meio ambiente (art. $1^{\circ}$ ), com todos os seus componentes, incluídos os microorganismos. Para o adequado cumprimento da citada Lei, compete aos órgãos de fiscalização do Ministério da Saúde, do Ministério da Agricultura e do Abastecimento e do Ministério do Meio Ambiente, dentre outras atribuições no campo das respectivas competências, observado o parecer técnico prévio conclusivo da CTNBio e os mecanismos estabelecidos em sua regulamentação: a) a fiscalização e o monitoramento das atividades e dos projetos relacionados a OGM; b) a emissão do registro de produtos contendo OGM ou derivados de OGM a serem comercializados para uso humano, animal ou em plantas, ou para a liberação no meio ambiente; c) a emissão de autorização para a entrada no País de qualquer produto contendo OGM ou derivado de OGM; d) manter cadastro de todas as instituições e profissionais que realizem atividades e projetos relacionados a OGM no Território Nacional (art. 7으. II, III, V, VI, com as alterações da Medida Provisória n. 2.1918, de 26.7.2001, MP revogada n. 2.137-6, de 21.6.2001). Determina a citada Lei que toda entidade que utilizar técnicas e métodos de engenharia genética deverá criar uma Comissão Interna de Biossegurança-CIBio, com atribuições, dentre outras, de: manter informados os trabalhadores, qualquer pessoa e a coletividade, quando suscetíveis de serem afetados pela atividade, sobre todas as questões relacionadas com a saúde e a segurança, bem como procedimentos em caso de acidentes; estabelecer programas preventivos e de inspeção para garantir o funcionamento das instalações sob sua responsabilidade (arts. 9º 10 , I, II). O Decreto $n$. 1.752, de 20.12.1995, regulamentando a Lei n. 8.974, de 5.1.1995, dispõe sobre a vinculação, competência e composição da Comissão Técnica Nacional de Biossegurança-CTNBio. A Medida Provisória n. 2.191-8, de 26.7.2001 (MP revogada n. 2.137-6, de 21.6.2001), acrescenta e altera dispositivos da Lei n. 8.974, de 5.1.1995, notadamente, sobre a criação, no âmbito do Ministério da Ciência e Tecnologia, da Comissão Técnica Nacional de Biossegurança-CTNBio, sua composição e competência. Definida como instância colegiada multidisciplinar, a CTNBio tem a finalidade de prestar apoio técnico-consultivo e de assessoramento ao Governo Federal na formulação, atualização e implementação da Política Nacional de Biossegurança relativa a OGM, bem como no estabelecimento de normas técnicas de segurança e pareceres técnicos conclusivos referentes à proteção da saúde humana, dos organismos vivos e do meio ambiente, para atividades que envolvam a construção, expe- 
rimentação, cultivo, manipulação, transporte, comercialização, consumo, armazenamento, liberação e descarte de OGM e derivados no meio ambiente. O Decreto n. 3.871, de 18.7.2001, disciplina a rotulagem de alimentos embalados que contenham ou sejam produzidos com organismos geneticamente modificado.

Apenas com uma breve análise do conteúdo e do alcance dos citados textos legais e regulamentares sobre OGM, em confronto com os vigentes princípios e normas constitucionais e legais, pode-se concluir que houve flagrantes omissões, insuficiências e incompatibilidades de normas ali previstas. Dentre as injustificáveis omissões, insuficiências e incompatibilidades de dispositivos legais e regulamentares sobre OGM, destacam-se as seguintes:

a) A Lei n. 8.974, de 5.1.1995, não obstante tratar de atividade efetiva e potencialmente causadora de significativa degradação do meio ambiente, com o emprego de técnicas e substâncias que comportem riscos para a vida, a qualidade de vida e a saúde pública, como aquelas relacionadas com o uso das técnicas de engenharia genética e liberação no meio ambiente de OGM, por meio de processos químicos e perigosos ou arriscados com manipulação e emprego de herbicidas ou agrotóxicos, seus componentes ou afins, omite, sem justificativa, a exigência do estudo prévio de impacto ambiental com o respectivo relatório de impacto ambiental-EPIA/RIMA, a que se dará publicidade, diante da pretensão de atividades e projetos sobre o complexo assunto, o que ofende flagrantemente as expressas normas constitucionais (CF, art. 225, $\S 1^{\circ}$, IV, V). Da mesma forma, a citada Lei omite normas sobre transparentes informações em embalagens ou rotulagens de produtos contendo OGM ou derivados de OGM, o que viola não só as fundamentais normas constitucionais dos direitos à informação e à defesa do consumidor, do direito à educação e do direito à conscientização pública (CF, art. $5^{\circ}, \mathrm{XXXII}, \mathrm{XXXIII}, \mathrm{c} / \mathrm{c}$ arts. $\left.170, \mathrm{~V}, 225, \S 1^{\circ}, \mathrm{VI}\right)$, mas também as normas legais (Lei n. 6.938, de 31.8.1981, arts. $2^{\circ}, \mathrm{X}, 4^{\circ}, \mathrm{V}, 9^{\circ}$, VII, XI; Lei $\mathrm{n}$. 8.078, de 11.9.1990 - Código de Defesa do Consumidor, arts. 6으, $7^{\circ}$, $9^{\circ}$ ). Trata-se de insuficiências ou omissões flagrantemente inconstitucionais, impondo-se as imediatas reflexões, por parte da comunidade científicojurídica e dos Poderes Públicos competentes, para elaboração de normas, particularmente, sobre a exigência tanto do estudo prévio de impacto ambiental e respectivo relatório de impacto ambiental-EPIA/RIMA perante projetos, atividades e aplicação que envolvam a liberação de OGM no meio ambiente, como de transparentes informações ambientais e em embalagens, rotulagens ou etiquetas de alimentos ou produtos contendo OGM ou derivados de OGM, no sentido de preencher as lacunas da Lei n. 8.974, de 5.1.1995, de forma compatível com as vigentes normas constitucionais e legais citadas, no legítimo interesse e em defesa aos direitos do consumidor.

b) Decreto regulamentar $n$. 1.752, de 20.12.1995. As normas do inciso XIV do art. $2^{\circ}$, do presente Decreto, atribuindo competência facultativa à CTN- 
Bio no sentido de "exigir, como documentação adicional, se entender necessário, Estudo de Impacto Ambiental (EIA) e respectivo Relatório de Impacto do Meio Ambiente (RIMA) de projetos e aplicação que envolvam a liberação de OGM no meio ambiente", são flagrantemente incompatíveis com as vigentes normas constitucionais (CF, art. 225, § 1, IV) e legais (Lei n. 6.938 , de 31.8.1981, arts. $9^{\circ}$, III, 10). Ora, tanto o estudo prévio de impacto ambiental (EPIA) com o respectivo RIMA, para autorização ou licenciamento de projetos e atividades perigosos ou arriscados potencialmente degradadores do meio ambiente, como o estudo de impacto ambiental (EIA) e respectivo relatório de impacto ambiental (RIMA) para renovação de autorização ou licenciamento ao prosseguimento de atividades efetivamente poluidoras, de forma prévia ou não, constituem relevantes instrumentos principais, obrigatórios, básicos, por força das normas constitucionais (CF, art. 225, $\S 1^{\circ}$, IV c/c V) e legais (Lei n. 6.938, de 31.8.1981, arts. 9o, III, 10), notadamente diante de projetos, atividades, aplicação, manipulação com 0 emprego de qualquer tecnologia ou biotecnologia que comporte risco ao meio ambiente, à qualidade de vida, à saúde pública. Desta forma, o EPIA/ RIMA ou o EIA/RIMA, como básico e preventivo instrumento obrigatório por imposição constitucional e legal, quer diante de atividade potencialmente degradadora ou de atividade efetivamente degradadora, como aquela que envolve OGM, não constitui alternativa, nem se confunde com mera documentação adicional ou facultativa ao arbítrio da CTNBio, demonstrando-se a flagrante inconstitucionalidade da norma do inciso IV do art. $2^{\circ}$ do Decreto n. 1.752, de 20.12.1995, que atribui competência optativa à CTNBio, para exigir, "se entender necessário", o EPIA/RIMA ou o EIA/RIMA.

Ora, a competência da CTNBio, por dever jurídico-constitucional, na prestação de serviço público em defesa da vida, da qualidade de vida, do meio ambiente e da saúde pública, longe de qualquer opção facultativa, se vincula ao cumprimento dos princípios e das normas constitucionais e legais vigentes. Tanto assim que, em oportuna decisão judicial, envolvendo parecer favorável da CTNBio ao pedido de desregulamentação da soja Roundup Ready feito pela Monsanto do Brasil, sem estudo de impacto ambiental, sem as mínimas normas de segurança alimentar, comercialização e rotulagem dos alimentos transgênicos, sem informações sobre os riscos decorrentes da liberação da "soja transgênica resistente ao herbicida Roundup", o ilustre Juiz Federal titular da 6 ${ }^{\text {a }}$ Vara da Seção Judiciária do Distrito Federal julgou procedente a ação, condenando "a União Federal a exigir a realização do prévio Estudo de Impacto Ambiental da Monsanto do Brasil Ltda.", de acordo com as disposições da Constituição Federal, do Código de Defesa do Consumidor e da legislação ambiental, para liberação de espécies geneticamente modificadas e de todos os outros pedidos formulados à CTNBio. Conseqüentemente, declarou "a inconstitucionalidade do inciso XIV do art. $2^{\circ}$ do Decreto n. 1.752/95, bem assim das Instruções Normativas 3 e 10 
- CTNBio, no que possibilitam a dispensa do EIA/RIMA, na espécie dos autos"(4).

c) Medida Provisória n. 2.191-8, de 26.7.2001 (MP revogada n. 2.137-6, de 21.6.2001). $O$ art. 1-D, definindo a competência da CTNBio para, dentre outras atribuições, "estabelecer critérios e monitoramento de risco de OGM" e proceder à avaliação de risco, caso a caso, relativamente a atividades e projetos que envolvam OGM, a ela encaminhados", omite, injustificada e reiteradamente, a competência da citada CTNBio, para exigir o estudo prévio de impacto ambiental (EPIA) com o respectivo relatório de impacto ambiental (RIMA), diante de atividades ou projetos que envolvam a liberação de OGM, o que viola flagrantemente as normas constitucionais (CF, art. 225,

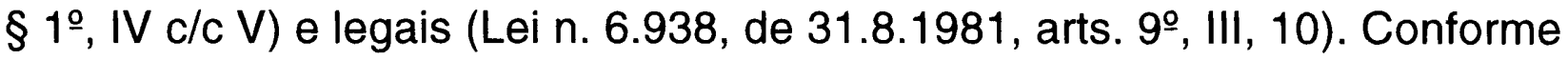
já se demonstrou, o EPIA/RIMA, como básico e preventivo instrumento essencial, por imposição constitucional e legal, obrigatório diante de projetos e atividades que envolvam OGM, potencialmente degradadoras e arriscadas contra o meio ambiente saudável, a vida e a saúde da pessoa humana, dos animais, das plantas e dos microorganismos, é inconfundível com providências normais e permanentes referentes a "critérios de avaliação e monitoramento de risco de OGM" ou "avaliação de risco, caso a caso, relativamente a atividades e projetos que envolvam OGM", como medidas necessárias e prudentes na execução dos respectivos planos de manejo ecológico ou de qualquer forma de monitoramento correlato. Evidentemente, o EPIA/ RIMA ou EIA/RIMA, para autorização ou licenciamento de atividade inicial potencialmente poluidora ou para renovação de autorização ou licenciamento de atividade já existente e efetivamente poluidora, referente à liberação de OGM no meio ambiente, fundamentado em regime jurídico constitucional e legal próprio e inconfundível, vinculado aos princípios da prevenção ou precaução de riscos ou danos ambientais e da conciliação ou compatibilização do desenvolvimento socioeconômico com a preservação do meio ambiente saudável, jamais será equivocado ou substituído por medidas normais de "avaliação de risco de OGM", de "avaliação e monitoramento de risco de OGM" ou de "parecer técnico prévio conclusivo", na execução de projetos e atividades sobre o complexo assunto, previstas nos incisos III, IV e XIV, do art. 1--D em análise.

Assim, diante da inconstitucional omissão da exigência do EPIA/RIMA ou EIA/RIMA e da respectiva publicidade obrigatória na norma em apreciação, bem como da injurídica confusão que resultou na substituição simuladamente ilegal do EPIA/RIMA ou EIA/RIMA pelas normas dos incisos III, IV e XIV do art. 1-D da presente Medida Provisória, impõem-se as imediatas providências da comunidade científico-jurídica, junto aos Poderes Públicos

(4) Organismos Geneticamente Modificados: Ação Civil Pública - Proc. 1998.34. 00.027682-0, Brasília (DF), - j- 26.6.2000, Juiz Federal Antonio Souza Prudente. In: Revista de Direito Ambiental v. 20/309, São Paulo: RT, 2000. 
competentes, para fins de adequação das normas criticadas à vigente Constituição, com o preenchimento das omissões mediante o acréscimo de normas legais com a introdução da exigência do EPIA/ RIMA ou EIA/RIMA diante de projetos e atividades que envolvam OGM, com transparente publicidade, sem prejuízo das providências normas decorrentes das atribuições do CTNBio definidas nos incisos III, IV, VIX, do art. 1--D, da Medida Provisória n. 2.191-8, de 26.7.2001 (MP revogada n. 2.137-6, de 21.6.2001), em apreciação.

Além do mais, a norma do inciso XVIII do art. 1ㅇ D da citada Medida Provisória n. 2.191-8, de 26.7.2001 (MP revogada n. 2.137-6, de 21.6.2001), tratando da competência da CTNBio para divulgar providências sobre processos que lhe forem submetidos, referentes ao consumo e à liberação do OGM no meio ambiente, exclui "as informações sigilosas, de interesse comercial, apontadas pelo proponente e assim por ela consideradas". Já perdendo a noção da realidade da atividade econômica vinculada à observância dos princípios constitucionais e legais vigentes em defesa e preservação do meio ambiente, da vida, da saúde, dos direitos do consumidor e das gerações presentes e futuras, a temerária exceção à publicidade constitui gravíssima confissão, com a conivência da CTNBio, do prosseguimento da prevalência de interesses econômicos de lucros imediatos de grandes empresas notadamente multinacionais, interessadas em liberação de OGM no meio ambiente brasileiro, em flagrante violação tanto aos direitos do consumidor e da coletividade em geral como aos princípios constitucionais e legais integrantes de nosso Direito Positivo (CF, arts. 5, XXXII, XXXIII, c/c arts. 170, V, VI, 220, §§ $3^{\circ}, \mathrm{II}, 4^{\circ}, 225 \S 1^{\circ}$, IV, V, VI; Lei n. 6.938, de 31.8.1981, arts. $2^{\circ}, \mathrm{X}, 4^{\circ}, \mathrm{V}, 9^{\circ}$, $\mathrm{VII}, \mathrm{XI}$; Lei n. 8.078, de 11.9.1990, arts. $\left.6^{\circ}, 7^{\circ}, 9^{\circ}\right)$. Não resta dúvida de que a norma do inciso XVIII em exame crítico, excluindo a publicação de relevantes informações referentes ao consumo e à liberação de OGM no meio ambiente por uma simples consideração subjetiva do proponente interessado em esconder a realidade do sigilo intencional apenas no "interesse comercial" ou na pessoal consideração da CTNBio, em efetivo ou iminente prejuízo dos direitos fundamentais e invioláveis à vida, à liberdade, à segurança, à saúde, ao meio ambiente saudável, viola flagrantemente as expressas disposições constitucionais e legais citadas, impondo-se a sua imediata revogação.

Ora, em matéria de interesse público, os vigentes princípios e normas constitucionais e legais mencionados, exigindo publicidade ampla, transparente e incondicionada, não definem qualquer exceção no tocante à exclusão de informação ou publicidade de interesse ambiental, uma vez que se trata de direito garantido a todas as pessoas, físicas ou jurídicas, de direito público ou de direito privado, com ou sem fins lucrativos. A Constituição determina expressamente o EPIA/RIMA com obrigatória e total publicidade, sem qualquer condicionamento publicitário, sem qualquer exceção de sigilo industrial, sem qualquer exceção de sigilo de interesse comercial. Neste sentido, adverte-se que o excepcional sigilo industrial ou o excepcio- 
nal sigilo comercial relacionado com os "Crimes de Concorrência Desleal" (Lei n. 9.279, de 14.5.1996, art. 195, XI) e o excepcional sigilo "imprescindível à segurança da sociedade e do Estado" (relacionada com a defesa do território nacional e com a segurança pública - CF, art. 5ํ, XXXIII, in fine, c/c arts. 91, § 1ํ, III, 144) não se aplicam às amplas e permanentes informações ambientais nem com estas se confundem, uma vez que as informações de natureza ambiental, juridicamente obrigatórias, são indispensáveis ao equilíbrio ecológico-ambiental, à saúde pública, à preservação da vida em geral e, conseqüentemente, ao fortalecimento da segurança da sociedade e do Estado, no legítimo interesse de todos. Evidentemente, a exceção da divulgação ou publicidade de informações sobre consumo ou liberação de OGM no meio ambiente, acintosamente contrária ao interesse público, com intencional alegação de "informações sigilosas de interesse comercial" particular e do lucro imediato, além de incompatível com as informações ambientais de interesse público, é flagrantemente inconstitucional e ilegal, uma vez que viola o conteúdo e o alcance das disposições citadas, impondo-se a sua imediata supressão, mediante revogação ou declaração de inconstitucionalidade com a suspensão de sua execução, por parte dos Poderes Públicos competentes, das normas do inciso XVIII, in fine, do art. 1--D da Medida Provisória n. 2.191-8, de 26.7.2001 (MP revogada n. 2.137-6, de 21.6.2001).

Quanto à composição da CTNBio, considerando a relevância, atualidade e complexidade do assunto, progressivamente sujeito a contraditórias repercussões práticas, uma vez que envolve todos os interesses da vida em sociedade disciplinados pelo Direito, é oportuno, ainda, salientar que, como instância colegiada multidisciplinar, para a formulação, a atualização e a execução da Política Nacional de Biossegurança, não se justifica a ausência de membros representantes de instituições da Ciência do Direito e da Justiça, com atribuições para elaboração de normas técnicas de segurança, de pareceres, de atualização e execução de Políticas Nacionais de interesse público, para a oportuna conciliação de interesses privados, sociais ou coletivos e públicos, de forma compatível com o Sistema Jurídico Brasileiro. A participação do advogado ou do jurista em geral se torna obrigatória diante de qualquer decisão de interesse social ou público, que implique 0 estabelecimento de regras de conduta para a ordem e o equilíbrio de interesses da própria sociedade a serviço da vida e ao bem-estar de todos. Nestas condições, torna-se necessária a introdução à composição da CTNBio de representantes notadamente de Instituições Defensoras do Direito, portanto, Essenciais à Justiça e à Administração da Justiça (Ministério Público, Advocacia Pública, Advocacia em Geral e Defensoria Pública - CF, arts. 127 a 134).

Em face das inconstitucionalidades e ilegalidades decorrentes do abuso do poder de legislar, é oportuno advertir que, por princípio geral do Direito, as normas gerais ou especiais novas, com objetivos compatí- 
veis com os das normas já existentes, não revogam nem modificam as normas anteriores, mas, sim, se complementam harmonicamente, no sentido de fortalecer a legislação vigente, ajustando-a às novas exigências sociais no interesse de todos ( $\mathrm{LI}$ ao $\mathrm{CC}$, art. $2^{\circ}, \S 2^{\circ}$ ). Assim, no tocante à matéria ambiental, prevista no Capítulo do Meio Ambiente da Constituição Federal (art. 225), convém recordar que as novas normas legais, reguladoras de seus dispositivos e compatíveis com seus objetivos ou suas finalidades, não revogam nem modificam as normas legais (gerais ou especiais) anteriores correlatas, mas, sim, se complementam, ainda que subsidiariamente, ao progressivo fortalecimento do Direito Ambiental Brasileiro(5), de forma continuamente ajustável à conciliação ou compatibilização das novas exigências do desenvolvimento socioeconômico e do progresso científicotecnológico com a preservação da qualidade ambiental propícia à vida, à saúde, à liberdade, à segurança de todos, no legítimo interesse das presentes e futuras gerações.

Deve-se examinar, também, os princípios constitucionais da conciliação do desenvolvimento socioeconômico com a preservação da qualidade ambiental propícia à vida, com a proteção do consumidor e a conservação da saúde pública. Trata-se de expressos princípios gerais da atividade econômica, vinculados ao princípio da prevenção ou da precaução de riscos ou danos ambientais, a serem obrigatoriamente atendidos de forma compatível com os princípios constitucionais, dentre outros: a) da soberania nacional, incluído o direito soberano de explorar seus próprios recursos segundo suas políticas ambientais, bem como a responsabilidade de assegurar que atividades sob sua jurisdição ou controle não causem dano ao meio ambiente de outros Estados ou de áreas além dos limites da jurisdição nacional; estabelecer ou manter meios para regulamentar, administrar ou controlar os riscos associados à utilização e liberação de organismos vivos modificados resultantes da biotecnologia que provoquem impacto ambiental negativo que possa afetar a conservação e a utilização sustentável da diversidade biológica, levando também em conta os riscos para a saúde humana; procurar proporcionar as condições necessárias para compatibilizar as utilizações atuais com a conservação da diversidade biológica e a utilização sustentável de seus componentes (Convenção sobre Diversidade Biológica, princs. 3 e 8 , "g", "i"); b) da função social da propriedade (pública e privada); c) da livre concorrência (não admite concorrência desleal nem monopólio); d) da defesa do consumidor (incluído o direito à liberdade de

(5) Neste sentido, adverte-se que a Medida Provisória n. 2.186-15, de 26-7-2001 (MP revogada $\mathrm{n}$. 2.126-13, de 22.6.2001), regulamentando o inciso /I do $\S 1^{\circ}$ do art. 225 da Constituição, dentre outros dispositivos, já regulamentado pela Lei n. 8.974, de 5.1.1995 - Lei da Biossegurança, sobre o dever do Poder Público "preservar a diversidade e a integridade do patrimônio genético do País e fiscalizar as entidades dedicadas à pesquisa e manipulação de material genético", expressamente dispõe que: "As disposições desta Medida Provisória não se aplicam à matéria regulada pela Lei n. 8.974, de 5 de janeiro de 1995" (art. 36). 
escolha notadamente de produto alimentar com transparente informação no rótulo, na etiqueta ou embalagem sobre a existência ou não de OGM ou derivado de OGM em defesa de sua saúde); e) da defesa do meio ambiente (incluída a defesa da sadia qualidade de vida) com todos os seus bens ou valores naturais (vivos e não-vivos), socioeconômicos, alimentares, sanitários, culturais, espirituais, recreativos, em todas as zonas, tanto urbana e de expansão urbana ou periférica como rural (CF, art. 170, I, III, IV, V, VI, c/c arts. $5^{\circ}$, II, XIII, XXIII, XXXII, XXXIII, XXXIV; 174; 180; 182; 185, 186, 187, 190; 196 a

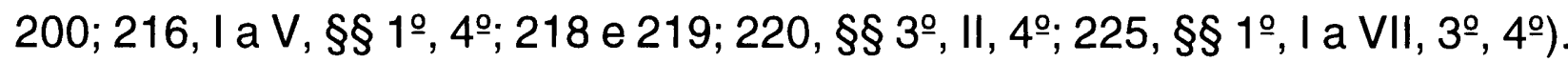

Por força do conteúdo e do alcance das normas constitucionais citadas, tanto a atividade econômica e o desenvolvimento socioeconômico como o progresso científico-tecnológico constituem direitos fundamentais, atribuídos a todas as pessoas, físicas e jurídicas, de direito público e de direito privado. Todavia, o exercício de tais direitos, longe de qualquer forma de monopólio, concorrência desleal ou conduta arbitrária, abusiva ou ilegal em prejuízo de outrem, sujeita o seu titular (pessoa física ou jurídica, de direito público ou de direito privado) à observância das limitações e proibições constitucionais e legais, em razão da imperiosidade dos princípios fundamentais da conciliação do desenvolvimento socioeconômico com a preservação da sadia qualidade ambiental propícia à vida, à liberdade, à segurança, à propriedade, à saúde pública, no legítimo interesse do equilíbrio social e do bem-estar de todos. Trata-se de expressos princípios constitucionais vinculados ao princípio da prevenção ou precaução de riscos ou danos ambientais, baseados nos milenares princípios da prudência, diligência, perícia, eficiência, introduzidos na Bíblia (Ecles. Cap. 18, 19 a 29; Sab. Cap. 8, 7 a 9 e Cap. 9, 11 a 15; Mat. Cap. 7, 24 a 27; Cap. 25, 1 a 13), consagrados e consolidados na legislação dos Países desenvolvidos e em via de desenvolvimento (como o Brasil), visando a combater e reduzir ou eliminar as causas ou os efeitos danosos previstos, prevenidos ou acautelados, reduzidos ou eliminados de atividades humanas arriscadas ou perigosas, no legítimo interesse não só das gerações passadas, mas especialmente das gerações presentes e futuras.

Em breves advertências críticas resumem-se, dentre as questões aplicáveis ao direito do consumidor em confronto com a problemática dos OGMs, as seguintes:

\section{NO DIREITO COMPARADO E NA COMUNIDADE EUROPÉIA}

No Direito Comparado, partindo da França, observa-se que a Lei $\mathrm{n}$. 92-654, de 13.7.1992, relativa ao controle da utilização e da disseminação dos organismos geneticamente modificados, institui uma nova regulamentação aplicável a toda utilização de organismos geneticamente modificados 
(OGMs). Esta Lei ultrapassa as Diretivas Européias n. 90/219/CEE de 23.4.1990 e 90/220/CEE de 23.4.1990, respectivamente, sobre a utilização limitada dos microorganismos geneticamente modificados e sobre a disseminação dos organismos geneticamente modificados. O Regulamento n. 1813/97 da Comissão, de 19.9.1997, dispõe sobre a menção obrigatória referente à etiquetagem de alguns produtos alimentares preparados a partir de organismos geneticamente modificados, além de outras informações previstas na Diretiva n. $97 / 112^{(6)}$. Notadamente após a vigência da citada legislação, observam-se permanentes debates referentes às crescentes polêmicas, de forma especial sobre: "questão ética e moral", "transgêneses e transgressão", "A desordem ecológica", "Os riscos para a saúde", "Os limites da engenharia genética", "O dossiê sócio-econômico", "Os Ogm e a opinião pública", "Etiquetagem, transparência, declaração de origem dos produtos", "Interesses financeiros colossais", "Por uma moratória". Em conclusão, torna-se patente "uma fratura" derivada da "crise de confiança nos confrontos do quadro científico", fratura esta que "divide não só os cientistas, mas também os políticos, a opinião pública", a "sociedade civil", em razão dos "riscos" impostos "do alto" que "não dependem de sua escolha", impondo-se o "dever de vigilância no sentido de preservar a herança" a ser entregue "às gerações futuras", mediante a observância de "maiores precauções" para que "os riscos sejam reduzidos ao mínimo e a população seja protegida ao máximo". Pela relevância do assunto, "não estão em jogo os interesses particulares", mas, sim, o interesse público, uma vez que convicta é a conclusão, segundo a qual se trata da defesa e da proteção "do interesse de todos"(7).

$\mathrm{Na}$ Itália, de acordo com o Relatório Anual de Legambiente, no capítulo das "atividades produtivas", evidencia-se "o risco das biotecnologias" no campo da agricultura. As biotecnologias entraram na fase do desenvolvimento e da comercialização de produtos "transgênicos", derivados de processos de manipulação genética, advertindo-se, dentre as preocupantes questões decorrentes, aquelas sobre "o seu potencial impacto sobre a agricultura e a alimentação", uma vez que "a difusão dos produtos biotecnológicos provoca numerosos problemas de ordem ambiental, sanitária e econômica". "Os efeitos, imediatos e a longo prazo, conexos à imissão no meio ambiente de organismos geneticamente modificados, são complexos", especialmente de plantas assim modificadas e empregadas na "agricultura intensiva", com a dependência do uso maciço de produtos químicos, cujo "resultado final é o risco muito concreto que as biotecnologias acelerem a perda da biodiversidade". Já se adverte que o perigo de "uma erosão sempre

(6) Code de L'Environnement - Protection de la Nature - Lutte contre les Nuisances, Paris: Dalioz, 1998 - Legislação sobre "Organismes génétiquement Modifiés", p. 1452 e segs.

(7) Pelt, Jean-Marie. L'Orto di Frankenstein - Cibi e piante transgenici, trad. do orig. francês, Milano: Feltrinelli, 2000, p. 11 e segs. 
mais rápida da diversidade é particularmente elevado na Itália", pois não há "precaução suficiente para garantir a salvaguarda da especificidade dos produtos típicos e locais". Além do mais, enquanto reina a "máxima incerteza" dos "efeitos indesejados sobre a saúde humana" dos OMGs no meio ambiente, "as vantagens econômicas decorrentes do emprego de tecnologias são de manifesta evidência" nas mãos de poucos, de grandes grupos industriais, com a limitação da autonomia dos agricultores, a redução da capacidade de escolha e do poder contratual, o que constitui perigo de cláusulas abusivas dos contratos impostos aos agricultores nos países onde se difundem as cultivações transgênicas. Além das questões previstas, torna-se cada vez mais discutível a perspectiva de sujeitar as biotecnologias ao mesmo regime de patente previsto para os normais produtos comerciais, advertindo-se que a "extensão automática da disciplina sobre patente à matéria vivente pode ter efeitos aberrantes". A questão da patente aplicável aos seres vivos, já prevista e em andamento em alguns Países (Estados Unidos, Japão, Alemanha, França, Reino Unido, Países Baixos, Itália), "põe em risco 'empobrecer' o patrimônio biológico e concentrar nas mãos de poucas multinacionais a propriedade dos produtos vegetais e animais". Com a expansão da liberação de OGMs em diversos países europeus (França, Itália, Reino Unido, Espanha, Alemanha, Países Baixos, Bélgica, dentre outros), conclui-se que a Itália, após a França, é o País em que foi efetuado o maior número de liberações no meio ambiente de OGMs, o que contribui para aumentar a preocupação tanto sobre os efeitos das biotecnologias como sobre as patentes de microorganismos modificados e das novas variedades vegetais, especialmente perante os Países em via de desenvolvimento. Reconhece-se a legitimidade de tecnologias inovadoras, mas não se admite o seu impositivo e automático emprego em "larga escala", concluindo-se sobre a necessidade de permanentes reflexões e providências para a fixação de "limites e vínculos claros à aplicação de biotecnologias", com a proibição de "empregos eticamente inaceitáveis"(8).

Neste sentido, diante dos "riscos alimentares representados pelos OGMs e pela conseqüente insegurança dos alimentos de nossa nutrição", de forma convicta, demonstra a doutrina especialista que "estes riscos representam só um aspecto da fúria biotecnológica", dando prioridade às "indústrias agroalimentares e químico-farmacêuticas", uma vez que existem outros riscos, além de "um altíssimo risco para um sistema de cultivação e criação frágil pela sua própria natureza", mormente com a iminência da obtenção de plantas transgênicas acostumadas "a doses maciças de herbicidas" ou agrotóxicos. Exibindo um "quadro geral da experimentação", com aplicações comercializadas em matéria de OGMs (nos Estados Uni-

(8) Legambiente - Associação Ambientalista Italiana, de ambito nacional, Ambiente Italia 2000 Rapporto Sullo Stato del Paese - Rapporto annuale di Legambiente, a cura dell'Istituto di Richerche Ambiente Italia, Milano: Ambiente, 1999, pp. 38, 39, 201, 202. 
dos, Canadá, Japão, na União Européia, com a prevalência da Monsanto, AgrEvo), pela confirmação dos gráficos, evidenciam-se "as finalidades da pesquisa biotecnológica: mais química e mais controle sobre o mercado das sementes" com a introdução de patentes e uma forte concentração nas mãos de "multinacionais", mediante "forte pressão", o que vem sendo enfrentado com prudência por países europeus, em face de "uma tecnologia que, além dos milagres prometidos, hoje não está ainda em grau de calcular antecipadamente os riscos iminentes contra a agricultura"(9). Sob este aspecto, "as preocupações relativas ao impacto sobre o meio ambiente são muito realísticas", por parte de pesquisadores, cientistas, em decorrência da "progressiva redução da biodiversidade e da variedade genética das plantas", além da preocupação dos consumidores com o aumento da "quantidade de substâncias químicas que vão lançar-se na cadeia alimentar e no meio ambiente", a falta de etiqueta ou rótulo nos produtos transgênicos, com o uso de ingredientes ou aditivos "danosos para a saúde humana", o que vem ocasionando "enorme desconfiança" dos OGMs e preferência por produtos não-transgênicos. Enquanto nos supermercados estadunidenses e canadenses cresce a quantidade de produtos transgênicos, na Itália, um crescente número de supermercados se declaram "GM free", ou seja, garantem que nos seus produtos não são utilizadas matérias primas geneticamente modificadas, salientando-se que a norma atual "impõe a obrigação de etiqueta sobre os produtos inteiramente transgênicos", isto é, "sobre os produtos nos quais foram empregados os OGMs", "mas não sobre os derivados". Não resta dúvida de que "as cultivações transgênicas constituem um risco ambiental" e o "emprego da agricultura biotecnológica implica uma grande quantidade de problemas éticos e políticos", além das questões sanitárias e das dúvidas no tocante à solução do "problema da fome" no mundo. Evidentemente, a solução alternativa mais segura e de aceitação geral é a da "agricultura sustentável", "agricultura orgânica" ou "agricultura biológica" (com restrições essenciais ao uso de agrotóxicos e antiparasitários) ${ }^{(10)}$.

Em razão das manifestas e crescentes inquietações notadamente dos consumidores, em alguns setores associativos de interesse econômico, já se evidencia a tendência à sensibilização por parte de alguns representantes conscientes dos problemas ambientais e dos interesses dos consumidores, mediante reflexões, estudos, conclusões e propostas. Neste sentido, dentre as questões relacionadas com os OGMs ou "as biotecnologias entre resistências, realizações e fugas" ou rejeições crescentes, destacam-se as seguintes: "A segurança do meio ambiente e da alimentação"; "O impacto ma-

(9) Onorati, Antonio. La sperimentazione biotecnologica in Italia, in L'orto di Frankenstein - Cibi e piante transgenici cit., p. 125 e segs. Sob este aspecto: Serra, Cristina. Gli organismi geneticamente modificati, Centro de Politica Estera - Osservatorio sulla Globalizzazione, Trieste: Asterios, 2000; Biotecnologie - Profili Scientifici e Giuridico - Sociali, Atti del Convegno, Catania, a cura di Bruno Montanari, Milano: Giuffré, 2000.

(10) Bussolati, Mariella e Morandi, Sabina. II gene nel piatto cit., pp. 17 e segs., 90 e segs., 100 e segs. 
croeconômico sobre os sistemas agroalimentares"; "Um desenvolvimento impetuoso mas controvertido"; "Potencialidade e aspectos críticos", com advertências sobre o aumento de "incertezas e resistências", de "discussão que se pretendia concluída em antecipação e que se reabre e revela a existência de uma série de dúvidas que pareciam superadas", como aquelas advertências subestimadas diante dos riscos e danos previsíveis da "central nuclear de Chernobyl" e do "mal da vaca louca" que , apesar da inexistência de evidência semelhante entre as questões, abre a reabre a questão da "prudência" diante do considerado "risco zero". Todavia, observa-se a resistência no tocante às "barreiras de segurança", argumentando-se que o "avançar do saber científico com suas recaídas" é inevitável, "mas não pode constituir um elemento freante quando todas as condições de garantia são cumpridas", como no caso das "propostas de moratória de 3 ou de 5 anos" que "conduzem a soluções não decisivas". Dentre as propostas ali previstas, evidenciam-se: "a prudente avaliação" da situação ou das perspectivas entre defensores e adversários da complexa questão "das biotecnologias agrárias"; "a comunicação" mediante a "difusão mais ampla possível de mensagens claras sobre a questão biotecnológicas" no sentido de vencer "a substancial ignorância" sobre o assunto, alimentada de um lado por contradições de mensagens e do outro lado por "substancial incapacidade científica de fazerse escutar e compreender", apesar de reconhecer-se que a "atual difusão da pesquisa, do desenvolvimento e da distribuição de OGM em escala mundial é sem sombra de dúvida fortemente irregular e isto constitui um elemento de resistência que pode exatamente ser removido"(11).

$\mathrm{Na}$ Comunidade Européia, no caso específico da problemática dos OGMs em confronto com os direitos do consumidor, dentre as diretrizes mais importantes aplicáveis no âmbito de sua competência, demonstramse: a) A Diretiva 90/220/CEE, de 23.4.1990, relativa à imissão voluntária no ambiente de organismos geneticamente modificados (OGMs), que estabelece os processos de avaliação de impacto ambiental e de autorização para a manipulação de OGM para fim de pesquisa ou para introdução no mercado, sem especificar o uso particular do produto, se para fins industriais, para alimentação humana ou animal, além da Diretiva 90/2207/CEE como base jurídica para a introdução no mercado dos OGMs. b) O Regulamento $n$. $258 / 97$ sobre os novos produtos e os novos ingredientes alimentares foi adotado pelo Parlamento europeu em janeiro de 1997. O novo Regulamento disciplina a introdução no mercado de produtos e dos ingredientes "novos", sendo o seu campo de aplicação mais amplo do que o da Diretiva 90/ 220 , pois inclui tanto os produtos que contenham diretamente os OGMs como aqueles obtidos a partir dos OGMs, ou seja, os chamados "derivados". Em vigor em 15.5.1997, o regulamento decreta que todos os produtos

(11) Nomisma - Instituto de Estudos Econômicos - VII Rapporto Nomisma sull'agricoltura italiana La Frontiera Biotecnologica, Milano: II Sole 24 ORE, 1999, pp. 56 e segs., 224, 244, 247 e segs. 
derivados de OGMs devam seguir "o processo de autorização previsto sobre os novos produtos", incluindo aqueles já autorizados pela Diretiva anterior, no caso de opção pelo seu emprego para fins alimentares. O Regulamento distingue, ainda, entre OGM e produtos derivados de OGM, de acordo com a etiqueta. Neste sentido, "há obrigação de etiquetar todos os produtos alimentares que contenham OGM enquanto, no caso dos derivados, há obrigação de etiqueta só se uma comissão de peritos os declara 'não equivalentes' aos produtos alimentares já existentes". Para evitar discrepâncias com os produtos OGMs conforme o Regulamento em exame, o Conselho adotou o Regulamento ad hoc n. 1139/98, com reconhecidas insuficiências sobre etiquetagem. c) Para o preenchimento das lacunas existentes, foram expedidos dois novos Regulamentos Europeus sobre etiquetas: n. 49/ 2000 e n. 50/2000, ambos de 10.1.2000. Enquanto o Regulamento (CE) 49/2000 modifica o Regulamento n. 1.139/98, amplia as suas normas para o cultivo, a colheita, o transporte, a conservação, a manipulação de material geneticamente modificado, o Regulamento 50/2000, ao contrário, trata especificamente dos aditivos e dos aromas geneticamente modificados ou produzidos mediante as técnicas de engenharia genética. Assim, quem utiliza aditivos ou aromas, contendo OGM, "há a obrigação de citar sobre a etiqueta, de modo claro e perfeitamente visível, a expressão 'derivado de ... geneticamente modificado'". Espera-se que estes dois importantes Regulamentos impeçam aos produtores a utilização de evasivas escapatórias, mediante o efetivo cumprimento de suas expressas normas no interesse particularmente dos consumidores ${ }^{(12)}$. No Brasil, não obstante a consagração constitucional da Política Sanitária, de forma harmônica e integrada com a Política Agrícola, a Política Econômica, a Política Educacional, a Política Ambiental, a Política científico-tecnológica e a existência de grande número de normas jurídicas protecionais do patrimônio sanitário humano, substâncias químicas, físicas ou biológicas de ação contra o meio ambiente e a saúde pública, tanto os agrotóxicos como seus afins e componente já se tornaram notórias fontes de poluição ambiental, distinguindo-o, de forma especial, pelo uso inadequado de agrotóxicos "como o terceiro maior consumidor do mundo"(13). Neste sentido, adverte a doutrina científica que "os países subdesenvolvidos, entre os quais o Brasil, absorvem $20 \%$ dos agrotóxicos produzidos no mundo", salientando que estes países, "ao mesmo tempo, são responsáveis por $75 \%$ das intoxicações com agrotóxicos"(14). O resultado da aplicação indiscriminada e excessiva de produtos contaminantes e altamente tóxicos já é a elevadíssima taxa de veneno no sangue da população

(12) La Normativa Nazionale e Internazionale sul Gli Ogm Nelle Leggi, in Bussolati, Mariella e Morandi, Sabina. II gene nel piato cit., p. 101 e segs.

(13) "A terra envenenada - Economia/Agricultura: os efeitos de uso de agrotóxicos", Revista Retrato do Brasil, 34/54; Neste sentido, Márcio Bontempo, Relatório ORION - Denúncia médica sobre os perigos dos alimentos industrializados e agrotóxicos, $3^{\text {a }}$ ed., Porto Alegre: L\&PM, 1986, p. 122 e segs. (14) Governo do Brasil, O Desafio do Desenvolvimento Sustentável - Relatório do Brasil perante a Conferência do Rio/92, cit., p. 129 e segs., demonstrando o quadro dos principais impactos 
brasileira, trazendo perigo para a saúde pública(15). Assim, adverte o cientista Antenor Ferrari que, enquanto "os ingleses têm 14,4 ppb (partes por bilhão) de veneno no sangue, os americanos $22,7 \mathrm{ppb}$, os argentinos 43,3 ppb", os brasileiros têm a impressionante taxa de " 572,6 ppb"(16). No caso específico da Política Nacional de Biossegurança diretamente relacionada com os organismos geneticamente modificados (OGMs), ${ }^{(17)}$ partindo da doutrina científica, destacam-se, dentre os principais aspectos, advertências e conclusões aplicáveis às biotecnologias e aos OGMs, os seguintes:

Em oportuna justificativa de não ser contra "a técnica da transgenia", que "não se quer causar atraso nenhum", nem retardar o avanço da agricultura brasileira, tornam-se evidentes os "efeitos conhecidos e potenciais dos transgênicos sobre a saúde humana e o meio ambiente". Enquanto a "tecnologia convencional é simples", seu "custo é baixo" e seus "benefícios" já conhecidos, a tecnologia transgênica "é sofisticada", seu custo "elevado" e seus benefícios "ainda precisam ser discutidos". Diante dos iminentes riscos, a observância do "princípio de precaução", a "avaliação dos impactos e riscos" e a "necessidade de análise de risco" dos transgênicos constituem, hoje, séria preocupação dos cientistas em defesa da saúde humana e do meio ambiente. Chernobyl "era um risco previsível, improvável de ocorrer, mas ocorreu", com conseqüências danosas irreparáveis. Sem observar as exigências legais, a CTNBio, "sem que os produtos tivessem registro", liberou "lavouras demonstrativas em 65 propriedades, sob a responsabilidade de agricultores", tudo de forma contrária ao princípio da precaução e das medidas preliminares de avaliação dos impactos ambientais, impondo-se as providências da comunidade científica junto ao governo em defesa da saúde humana(18).

ambientais, decorrentes, dentre outras atividades perigosas, da pulverização de agrotóxicos com o uso de avião ou de outros instrumentos, da aplicação maciça, do alto consumo, do uso de grandes quantidades de agrotóxicos em todas as Regiões do País; Unicamp - Área de Saúde Ambiental e Toxicologia, Informações Médicas de Urgência nas intoxicações por produtos agrotóxicos, Ministério da Saúde, Secretaria de Vigilância Sanitária e Divisão de Meio Ambiente e Ecologia Humana, Relatório: Programa de Teinamento, Unicamp-SP, 1996; Comissão de Cidadania e Direitos Humanos - Assembléia Legislativa-RS, Relatório Azul 1995, com sérias advertências sobre "Suicídio e uso de agrotóxicos em Venâncio Aires e outros locais", Diretoria de ANAIS/RS, p. 243 e segs.; Revista Globo Ciência, "Uma epidemia de suicídios" - "Ecologistas culpam os agrotóxicos da lavoura do fumo", Ver. GC, a. 6, n. 64, pp. 28 a 31, ed. nov/96. Neste sentido, reporta-se ao nosso trabalho: Agrotóxicos no Sistema Legal Brasileiro, in Revista de Direito Ambiental v. 8/139, Ed. RT-SP, 1997.

(15) Ferrari, Antenor. Agrotóxicos - a praga da dominação, cit., pp. 43, 44. Neste sentido: Elza Flores Rüegg e outros, Impacto dos Agrotóxicos sobre o meio ambiente, a saúde e a sociedade, Ícone-SP, 1986, p. 10; Bontempo, Márcio. Relatório Orion - Denúncia médica, cit., p. 124 e segs. (16) Ferrari, Antenor, ob. cit., p. 44, nota de rodapé 2.

(17) Neste sentido, Senado Federal, Seminário Internacional sobre Biodiversidade e Transgênicos, 24 e 25.6.1999, em Brasília, Anais, Senado Federal, 1999; 4 Congresso Internacional de Direito Ambiental, Agricultura e Meio Ambiente, de 4 a 7 de junho de 2000, Conclusões, in Anais do $5^{\circ}$ Congresso Internacional de Direito Ambiental sobre "O Futuro do Controle da Poluição e da Implementação Ambiental, organizado por Antônio Herman Benjamin e José Carlos Meloni Sícoli, de 4 a 7.6.2001, ANAIS, Imprensa Oficial-SP, 2001, p. inicial.

(18) Nodári, Rubens. Efeitos conhecidos e potenciais dos transgênicos sobre a saúde humana e o meio ambiente, in Anais do Seminário Internacional sobre Biodiversidade e Transgênicos, Senado Federal, Brasília, 1999, p. 141 e segs. 
Neste sentido, notória foi a preocupação dos consumidores ingleses com a qualidade dos alimentos e com a questão da "doença da vaca louca". No Brasil, o IDEC afirma não ser contra o avanço da ciência, mas adverte a sua preocupação sobre a conduta da CTNBio que, sem observar as exigências preventivas legais, vem autorizando tanto "experimentos para obtenção de plantas transgênicas" como "a importação e reexportação de soja geneticamente modificada", além da emissão do "famoso parecer favorável para que a soja da Monsanto fosse plantada e industrializada, comercializada e consumida por nós, aqui no Brasil". Adverte, igualmente, que a CTNBio insiste em "afirmação categórica: não há riscos", concluindo "que não há evidência de risco ambiental ou de riscos à saúde humana ou animal decorrentes da soja geneticamente modificada em questão". No caso dos alimentos, "os médicos britânicos já estão pedindo moratória, até que haja um consenso sobre o potencial de efeitos ambientais a longo prazo", pedido este apoiado pelas ONGs de consumidores, pela Associação Médica Britânica, o mesmo no Brasil pela SBPC e outras ONGs. ${ }^{(19)}$.

Além disso, sérias são as advertências, segundo as quais: $A$ nova Lei de Patentes (Lei n. 9.279/96) "permite o monopólio sobre processos biotecnológicos" e a Lei de Cultivares (Lei n. 9.456/97) "proíbe a reprodução comercial de sementes "protegidas", o que fortalece o setor privado detentor das novas biotecnologias que "espera poder deslocar os melhoristas públicos e substituir qualquer concorrência na distribuição e venda de sementes para as culturas de espécies que não se prestam à hibridização", sendo os primeiros resultados no "mapa da produção de sementeira" já visíveis e preocupantes. Exemplifica-se que a Monsanto, na venda de sementes de milho, já comprou "três das cinco maiores empresas melhoristas", passando "de zero para dominar $60 \%$ do mercado nacional" (de 1997 a 1999). A "mudança mais dramática é o avanço da Monsanto", com a perda de terreno da Embrapa (Empresa Pública) mesmo antes da introdução comercial da soja transgênica. Denuncia-se que a CTNBio, com amplas competências, tem autorizado "importação ao Brasil" de soja e milho em grão, óleo de soja e outros "alimentos transgênicos", da Argentina e dos Estados Unidos antes e depois de 1997, acrescentando-se que a "Argentina exporta 1,5 milhão de toneladas/ ano de milho de navio, principalmente para o Nordeste do Brasil", tudo sem informações aos consumidores sobre a sigilosa introdução de OGMs no "mercado brasileiro" e com a ilícita transformação de uma exceção legal (dada à CTNBio) em regra geral, o que é mais uma ilegalidade denunciada por cientista participante do evento, que pede o imediato cumprimento da Lei de Biossegurança e providências contra "o monopólio absoluto aprovado na atual Lei de Propriedade Industrial"(20).

Além da luta contra a concentração de competências em poder da CTNBio e a Lei das Patentes, reiteradas são as advertências contra os impactos dos

(19) Lazzarini, Marilena. Transgênicos: Iniciativas em defesa dos consumidores e o Direito de Precaução no Brasil, in Anais do Seminário Internacional sobre Biodiversidade e Transgênicos, cit., p. 195 e segs. No Tocante à ação civil pública citada, reporta-se à nota (7) desta exposição.

(20) Hathaway, David. Biotecnologia e Biossegurança, in Anais do Seminário Internacional sobre Biodiversidade e Transgênicos, cit., p. 31 e segs. 
"produtos transgênicos no meio rural", já se demonstrando que "o princípio ativo do herbicida Roundup, da Monsanto, de amplo espectro, elimina todas as plantas sobre a qual se aplica e que não tenham resistência ao mesmo"; sua aplicação "promoverá uma maior erosão genética no nosso capital genético". A problemática se agrava, de forma especial, se for considerado que cerca de "78\% do glifosate aplicado com pulverizador vai para outros lugares", com enormes custos "da erosão genética", "com o tratamento das pessoas afetadas" pela poluição decorrente "da aplicação do Roundup", com o tratamento de "toxidade subaguda ou toxidade crônica", de "depressão do sistema imunológico, desordem do sistema nervoso central", de "enfermidades da pele, câncer, mutações", de "toxidade ambiental com efeitos sobre a flora e a fauna", o que, além de forçar o abandono de agricultores do meio rural, em maléfico êxodo rural, para viver nas grandes metrópoles, geralmente em condições miseráveis, com o agravamento da marginalização e das "situações chocantes das populações urbanas" sem teto, em favelas, cortiços, contribui para o aumento dos custos notadamente socioeconômico-ambientais, o agravamento da perda dos valores familiares, culturais, tudo impondo imediatos "caminhos para vias alternativas"(21). Evidenciam-se, ainda, outras sérias advertências, denúncias e considerações similares sobre os direitos do consumidor em confronto com a complexa problemática dos organismos geneticamente modificados, com sugestões ajustáveis à realidade brasileira, tanto por parte da comunidade técnicocientífica $^{(22)}$ e da comunidade política ${ }^{(23)}$ como da comunidade jurídica ${ }^{(24)}$.

(21) Carvalho, João Luiz Homem de. Impactos das biotecnologias na agricultura agrária e soberania alimentar, in Anais do Seminário Internacional sobre Biodiversidade e Transgênicos, cit., p. 63 e segs. (22) Homma, Alfredo Kingo Oyama, Patrimônio genético da Amazônia, como proteger da biopirataria?, denuncia: a "fragilidade da economia extrativa como convite para a biopirataria", a "movimentação de recursos genéticos da Amazônia para outras áreas do País", a "biopirataria com objetivo de plantio econômico e patenteamento", Tabela de "Produtos da flora amazônica patenteados no exterior" (especialmente Estados Unidos e Japão), advertindo que a Lei n. 9.279, de 14.5.1996, "reconhece patentes de novo princípio ativo e drogas", o que constitui "um convite à biopirataria de plantas medicinais, inseticidas naturais e corantes", impondo-se novos conceitos jurídicos sobre esta questão, bem como a ampliação da Lei $n$. 9.456, de 25.4.1997, "para proteger as plantas nativas da Amazônia", in Anais, cit., p. 95 e segs.; Cordeiro, Ângela. Transgênicos: Conceitos, evolução, conseqüências sociais e para a pesquisa agrícola no Brasil, adverte sobre os impactos ambientais dos OGMs, propõe a adoção de "agricultura sustentável", com base em uma "ciência de alta qualidade, quando discutimos biossegurança", in Anais, cit., p. 133 e segs; Hoffmann, José Hermeto. Fundamentos técnicos e jurídicos para a instituição de áreas livres de transgênicos, justifica porque é "contra os transgênicos e a favor de uma zona livre de OGM em território gaúcho, com séria crítica contra a CTNBio que, numa composição mistificada, "não tem credibilidade para tratar desse tema", uma vez que constitui "uma instância técnica extremamente comprometida com os interesses das multinacionais"; conclui pela necessidade inadiável de "despertar a consciência popular", in Anais, cit., p. 167 e segs.

(23) Ferro, Fernando. Transgênicos: Poder Legislativo e a participação dos Partidos Políticos, critica a "arrogância do pessoal da CTNBio" e a posição de seu Presidente "contra a rotulação", o que gera "desconfiança e incerteza", adverte que a "Lei das Patentes foi aprovada por exigência do governo americano, foi aqui trazida e imposta" por "interesses comerciais dos Estados Unidos" com "o lucro e a venda da vida", impondo-se "o debate político sério", a "luta contra esse poder gigantesco" ao caminho da verdade em defesa dos "interesses da população, da sociedade", in Anais, cit., p. 203 e segs.

(24) Rios, Aurélio Virgílio Veiga. O Direito da Biodiversidade, evidencia "a obrigatoriedade do estudo de impacto ambiental" imposto pela Constituição e pela Convenção sobre Diversidade Biológica, bem como o dever de "garantir ao consumidor o direito de ser devidamente informado" sobre o 
Com estas breves mas claras advertências, denúncias e sérias considerações da idônea comunidade científico-técnica e político-jurídica alienígena e nacional, demonstra-se que grave é a problemática dos OGMs e das respectivas violações aos direitos do consumidor nos âmbitos do Direito Comparado e do Direito Pátrio. No caso específico do Brasil, a problemática dos OGMs, em confronto com os vigentes princípios e normas nacionais e internacionais, vem dando oportunidade para procedentes debates científico-jurídicos e vem provocando questões jurídicas de altíssima relevância: a) Omissão de normas legais sobre a exigência constitucional do EPIA/RIMA ou EIA/RIMA; b) Omissão de normas legais sobre informações, publicidade em rótulos de alimentos com OGMs (advertindo-se que o recente Decreto n. 3.871, de 18.7.2001, além de limitar e não tratar da "rotulagem abrangente" de alimentos com OGMs, é insuficiente e não substitui as normas legais), bem como inconstitucionalidade de norma excepcional sobre sigilo de informações de interesse comercial de produtos contendo OGMs; c) Inconstitucionalidade de normas que excluem leis compatíveis entre si e referentes ao mesmo dispositivo constitucional sobre manipulação de material genético do País; d) Inconstitucionalidade de normas legais sobre concessão de patentes e monopólio de microorganismos e plantas transgênicos (de forma contrária à soberania nacional, à livre concorrência, além de contribuir para o aumento da marginalização, da pobreza e das desigualdades sociais); e) Insuficiência de normas legais sobre a composição da CTNBio, diante da omissão de "especialista de notório saber jurídico", para a indispensável observância dos princípios constitucionais da prevenção de danos ambientais e da conciliação de interesses envolvidos em OGMs, dentre outras polêmicas questões jurídicas aplicáveis aos OGMs. Indubitavelmente, as reiteradas ilegalidades e o resistente abuso de poder, em flagrante desrespeito aos princípios e às normas constitucionais e legais, com as conseqüentes violações aos direitos do consumidor e da coletividade, ao princípio da soberania nacional, provocam, o recrudescimento das incertezas tanto dos consumidores como da sociedade civil e respectivas repercussões práticas, já com inéditas decisões judiciais ${ }^{(25)}$.

complexo assunto, in Anais, cit., p. 111 e segs.; Alencar, Gisela. Transgênicos: aspectos jurídicos e políticos, Debatedora, adverte sobre as ilegalidades cometidas pela CTNBio, liberando " 400 plantios demonstrativos" sem previsão na legislação, impondo-se sérias reflexões sobre a biossegurança, in Anais, cit., p. 179 e segs. Neste sentido, Donato, Margarida De. A Pequena Agroindústria e o Meio Ambiente, Dissertação de Mestrado, defendida e aprovada perante a Faculdade de Direito da USP, São Paulo, 1997, evidencia, dentre outros aspectos atuais, a relevância da "Agricultura Sustentável" e da "Agricultura Orgânica" como ramo da primeira, pp. 130, 132. Édis Milaré, Direito do AmbienteDoutrina - prática - jurisprudência - glossário, Ed. RT-SP, 2000, p. 171 e segs.; Machado, Paulo Affonso Leme. Direito Ambiental Brasileiro, 8. ed., Ed. Malheiros-SP, 2000, p. 35 e segs., evidencia a relevância do "princípio da precaução" perante a "Engenharia Genética".

(25) Além da importante decisão judicial citada na nota (4) desta exposição, demonstram-se, ainda, as seguintes: 1) Cultivo de Organismo Geneticamente Modificado - Mandado de Segurança - Soja transgênica roundup ready. CTNBio. Falta de expressa autorização do Poder Público Federal (Ministérios da Saúde, do Meio Ambiente e da Agricultura) e da licença ambiental da 
Ora, as omissões intencionais de normas legais, a importação de normas alienígenas contrárias aos princípios e às normas constitucionais e internacionais (em vigor no Brasil), o desconhecimento intencional (doloso) ou por negligência, imprudência ou imperícia (culposo) por parte de agentes do Poder Público ou de representantes de órgão colegiado de "notório saber científico e técnico", com o dever constitucional de conhecer, entender e cumprir a vigente legislação do próprio País, como a CTNBio, constituem condutas retrocessivas e violadoras tanto dos princípios e das normas constitucionais e legais nacionais (CF, art. 170, I, IV, V, VI, VII, c/c arts. $1^{\circ}, \mathrm{I}, \mathrm{II}, \mathrm{III}, \mathrm{IV}, 3^{\circ}, \mathrm{III}, \mathrm{IV}, 5^{\circ}, \mathrm{II}, \mathrm{XIII}, \mathrm{XXXII,}$ XXXIII, XXXV, 23, X, 37 e $\S \S 4^{\circ}, 5^{\circ}, 6^{\circ}$, $186,187,200$, I a VIII, 216, 218, 220, §§ 3으, II e 4으, 225, § Iㅇ, II, IV, VI, VI, VII, $\S \S 3^{\circ}$, 4ㅇ; CC, art. 159; Lei n. 6.938, de 31.8.1981, sobre a Política Nacional do Meio Ambiente; Lei n. 8.078, de 11.9.1990, sobre a proteção e defesa do consumidor) como internacionais (Decreto n. 2.519, de 16.3.1998, promulga a Convenção sobre Diversidade Biológica, em vigor no Brasil a partir de 29.5.1994, arts. 3ㅇ, 8ㅇ, g, h, i, j, k, 10, b, c, d, e, 12, 13, 14, 16, 19), tudo impondo inadiáveis reações e permanentes providências notadamente por parte da comunidade científico-jurídica do País, junto aos Poderes Públicos competentes, em defesa e preservação não só dos direitos do consumidor e da coletividade, mas também do meio ambiente saudável, da saúde pública e da própria soberania nacional, em prol do equilibrado desenvolvimento socioeconômico-ambiental no interesse de todos ${ }^{(26)}$.

\section{DEVERES E RESPONSABILIDADES RELATIVOS ÀS NORMAS SOBRE O DIREITO DO CONSUMIDOR E OS ORGANISMOS GENETICAMENTE MODIFICADOS NO BRASIL}

Por força dos princípios e normas constitucionais vigentes, expressas são a autonomia e as competências de todas as Unidades da Federação de forma harmônica e integrada, para legislar sobre matérias de interesse dos respectivos territórios, executar ou cumprir, adequar, atualizar e

autoridade competente - Lei n. 8.974/95 c/c Lei n. 6.938/81. llegalidade que põe em risco a saúde e o meio ambiente, com base em parecer técnico da CTNBio. Concedida a segurança impetrada por Monsoy, deu-se provimento ao Recurso do Estado do Rio Grande do Sulpara denegar a segurança, com a interdição da atividade ilegal - MS 70000027425 - 2a C.Cív.-TJRS - j. 6.10.1999, Rela. Desa. Maria Isabel de Azevedo Souza, in Rev. de Direito Ambiental v. 18/347. 2) Plantas Transgênicas - Ação Direta de Inconstitucionalidade proposta pelo Ministério Público do RS, visando a retirar do ordenamento jurídico a Lei n. 2.015/99 do Município de Não-Me-Toque-RS, que dispõe sobre o cultivo de plantas transgênicas na área agricultável do Município, matéria que não é de sua competência (CF, art. $24, \S 3^{\circ}$ ). Inconstitucionalidade. Julgada procedente a ADIN, declarou-se a inconstitucionalidade da Lei 2.015/99 do Município de Não-Me-Toque-RS, por violação à CE-RS (arts. $8^{\circ}, 10$ ) e CF (arts. 24, VI, 225) - ADIn 700000625152 - TJRS - j. 7-8-2000, Rel. Des. Vasco della Giustina, in Rev. de Direito Ambiental v. 21/314.

(26) Reporta-se ao nosso trabalho: "Uma Introdução à Responsabilidade Civil por Dano Ambiental". In: Revista de Direito Civil, Imobiliário, Agrário e Empresarial v. 75/69, São Paulo: RT, pp. 78, 79. 
aplicar as normas correlatas, ou fiscalizar sua observância, de forma ajustável às exigências sociais concretas ao bem-estar de todos. Conseqüentemente, por força de tais princípios e normas constitucionais e legais correspondentes, além dos direitos, competências ou poderes juridicamente atribuídos às pessoas físicas ou jurídicas, expressos são os deveres e as responsabilidades impostos à Administração Pública direta e indireta de qualquer dos Poderes da União, dos Estados, do Distrito Federal e dos Municípios, ou de qualquer pessoa física ou jurídica de direito privado prestadora de serviços públicos relacionados com a saúde, para o desempenho, de forma permanente, preventiva e eficaz, de suas atribuições, sempre sujeita à obrigatória obediência aos princípios da legalidade, impessoalidade, moralidade, publicidade, probidade, eficiência, dentre outros, no interesse público (CF, art. 37). Em matérias de agricultura, segurança alimentar, saúde e meio ambiente asseguradas pelos princípios e normas constitucionais e legais, integrantes, respectivamente, do Direito Agrário, do Direito Sanitário e do Direito Ambiental, tais deveres e responsabilidades, além de inerentes aos Poderes Públicos, estedem-se à coletividade (pessoas físicas ou jurídicas de direito privado, com ou sem fins lucrativos) por determinação constitucional (CF, arts. 196, 197, 200, c/c arts. 5ํ, XXXV, 21, $X X I I I$, “c”, 225, § 3).

Trata-se de princípios e normas fundamentais, de caráter obrigatório, impondo deveres inerentes à "contínua vigilância do todos"(27), particularmente da comunidade jurídica do País que tem o dever de defender a Constituição, de lutar pela boa aplicação das leis, pela rápida administração da Justiça, pela permanente promoção da educação ambiental, educação sanitária, educação agrícola, educação científico-tecnológica, educação jurídica, pelo aperfeiçoamento da cultura e das instituições jurídicas do País (CF: Poder Judiciário, arts. 92 a 126; Funções Essenciais à Justiça, arts. 127 a 135; princípios da educação ambiental, da prevenção ou precaução de danos ambientais, da conciliação de interesses ou do desenvolvimento sócioeconômico com a preservação ambiental (CF, arts. $5^{\circ}$, II, XXXII, XXXIII, XXXIV; 170, I, III, IV, V, VI, VII; 186, 187; 196 a 200; 216; 218; 220, §§ 3ㅇ, II, 4; 225, §§ $1^{\circ}$, I a VII, §§ 2 a 6o; Lei n. 8.906, de 4-7-94, art. 44, I), visando à promoção do bem de todos (CF, art. 3, IV). Os básicos princípios e normas constitucionais e legais devem tornar-se, cada vez mais, "efetivos e eficientes", uma vez que a Constituição, sendo "a égide da paz, a garantia da ordem", tem "em mira os fins", fornece "meios para os atingir", devendo os responsáveis "descobri-los e aplicá-los" ao bem de todos ${ }^{(28)}$. Assim: "É necessário compreendê-la corretamente, saber o que é a Constituição e como ela deve ser

(27) Miranda, Pontes de. Comentários à Constituição de 1967 com a Emenda n. 1, de 1969, T. I, 2. ed., São Paulo: RT, 1973, p. 402.

(28) Maximiliano, Carlos. Hermenêutica e Aplicação do Direito. 9. ed., Rio de Janeiro: Forense, 1979, pp. 306, 312. 
elaborada e aplicada para que possa atingir suas finalidades ${ }^{(29)}$, no legítimo interesse de todos.

Evidencia-se, portanto, que o descumprimento das vigentes imposições constitucionais e legais correspondentes, com as conseqüentes contaminações agrícolas e alimentares, lesões ao meio ambiente, à saúde e à vida, sujeitará a autoridade pública, o servidor ou qualquer agente competente, ou qualquer pessoa física ou jurídica de direito privado infratora, às responsabilidade e respectivas sanções éticas ou disciplinares, políticas, administrativas, civis, penais ou criminais aplicáveis de acordo com as circunstâncias de cada caso concreto. Assim, será necessário:

1. A revisão redacional da Lei $n$. 8.974, de 5.1.1995, e da respectiva Medida Provisória n. 2.191-8, de 26.7.2001 (MP revogada n. 2.137-6, de 21.6.2001), para os fins de complementação com a introdução de normas sobre exigência do Estudo Prévio de Impacto Ambiental (EPIA) e respectivo Relatório de Impacto Ambiental (RIMA) para as atividades potencialmente degradadoras, sem prejuízo do Estudo de Impacto Ambiental (EIA) e respectivo Relatório de Impacto Ambiental (RIMA) para atividades efetivamente poluidoras e em lesivo prosseguimento, com a clara publicidade correlata, diante de atividades ou projetos que envolvam OGMs, de forma compatível tanto com as vigentes normas constitucionais e legais (CF, art. 225, $\S 1^{\circ}$, IV, $\mathrm{V}, \mathrm{VI}$; Lei n. 6.938, de 31.8.1981, art. 9, III, c/c art. 5, parágrafo único) como com os princípios da prevenção ou precaução de danos ambientais e da conciliação do desenvolvimento socioeconômico com a preservação do meio ambiente saudável (CF, art. 5, XXXII, XXXIII, c/c arts. 24, VI, VIII, XII, 37, 170, V,

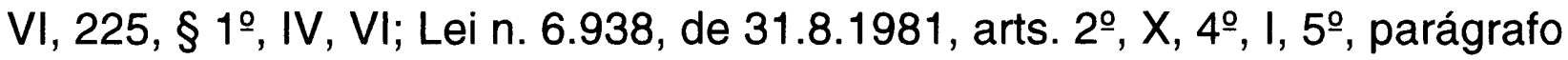
único; Convenção sobre Diversidade Biológica, art. 14).

2. A revisão redacional da Lei n. 8.974, de 5.1.1995, e da respectiva Medida Provisória n. 2.191-8, de 26.7.2001 (MP revogada n. 2.137-6, de 21.6.2001), para os fins de complementação com a introdução de normas sobre a exigência de rótulos ou rotulagens, embalagens, etiquetas, bulas ou cartazes de divulgação de alimentos transgênicos ou contendo organismos geneticamente modificados-OGMs ou derivados de OGMs, agrotóxicos, aditivos, seus componentes e afins, com a indicação das doses cientificamente recomendáveis e seguras, as informações claras (nome científico e respectivo nome vulgar ou comum) de todos os OGMs, agrotóxicos ou aditivos ali usados, tudo de forma transparente que se trata de "alimentos geneticamente modificados", "alimentos com OGMs" ou "alimentos com derivados de OGMs", alimentos com ou sem agrotóxicos", "alimentos com aditivos", "alimentos irradiados", com a definição dos respectivos processos adotados e das substâncias químicas empregadas, seu teor nutricional, sua segurança alimentar e os específicos ou eventuais efeitos colate-

(29) Dallari, Dalmo de Abreu. Constituição e Constituinte, 3. ed., São Paulo: Saraiva, 1986, p. 14. 
rais nocivos contra a saúde humana, dos animais, dos vegetais, dos microorganismos e do meio ambiente, de forma compatível com os vigentes princípios e normas constitucionais e legais (CF, art. 5ㅇ, XXXII, XXXIII, c/c

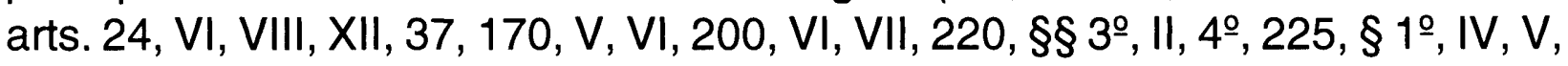
VI; Lei n. 6.938, de 31.8.1981, arts. $2^{\circ}$, X, $4^{\circ}$, V, $9^{\circ}$, VII, XI; Lei n. 7.802, de 11.7.1989, art. $7^{\circ}$, com as alterações da Lei n. 9.974, de 6.6.2000) ${ }^{(30)}$.

3. O reexame da norma excepcional do inciso XVIII do art. 10-D da Medida Provisória n. 2.191-8, de 26.7.2001 (MP revogada n. 2.137-6, de 21.6.2001), para os fins da supressão da exclusão das informações sigilosas de interesse comercial que envolvam OGMs, mediante revogação ou declaração de inconstitucionalidade com a suspensão de sua execução, por parte dos Poderes Públicos competentes (Executivo ou Judiciário e Legislativo), uma vez que é contrária aos princípios e normas constitucionais e legais de interesse do consumidor, coletivo, comum ou difuso, geral ou

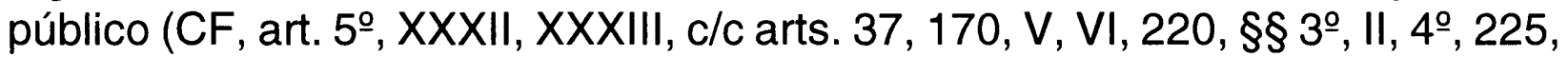
$\S 1^{\circ}, \mathrm{IV}, \mathrm{V}, \mathrm{VI}$; Lei n.6.938, de 31.8.1981, arts. $2^{\circ}, \mathrm{X}, 4^{\circ}, \mathrm{V}, 9^{\circ}$, VII, XI; Lei n. 8.078, de 11.9.1990, arts. $6^{\circ}, 7^{\circ}$, $9^{\circ}$ ).

4. O reexame da norma do art. 36 da Medida Provisória n. 2.186-15, de 26.7.2001 (MP revogada n. 2.126-13, de 22.6.2001), para os fins da supressão da exclusão da matéria regulada pela Lei n. 8.974, de 5.1.1995, sobre a regulamentação do mesmo inciso II do $\S 1^{\circ}$ do art. 225 da Constituição, referente à manipulação de material genético integrante do patrimônio genético do País, mediante revogação ou declaração de inconstitucionalidade com a suspensão de sua execução, por parte dos Poderes Públicos competentes (Executivo ou Judiciário e Legislativo), uma vez que é contrária às normas constitucionais e legais compatíveis entre si e de manifesto interesse público (CF, art. 225, $\S 1^{\circ} \stackrel{\circ}{ }$ II, LI ao CC, art. $2^{\circ}$, $\left.\S 2^{\circ}\right)^{(31)}$.

5. A revisão redacional das normas do inciso III do art. 18 da Lei $n$. 9.279, de 14.5.1996 (propriedade industrial ou Lei das Patentes), do art. $2^{\circ} \mathrm{e}$ dos incisos I e II do $\S 1^{\circ}$ do art. 10 da Lei n. 9.456, de 25.4.1997 (Lei de Proteção de Cultivares), para fins de alteração com a substituição das temerárias normas sobre concessão de patentes dos microorganismos transgênicos e de plantas, com a permissão de monopólio sobre os mesmos e a proibição de sua utilização no País, a não ser mediante a autorização do titular do direito da propriedade intelectual por meio de pagamento e venda de sementes, por outros dispositivos claramente compatíveis com os princípios e as normas nacionais, de forma especial, sobre a "soberania nacio-

(30) Observa-se que o recente Decreto n. 3.871, de 18.7.2001, além de não tratar da "rotulagem abrangente" de alimentos com OGMs, é insuficiente e não substitui a eficácia e a força de expressas normas legais em defesa e proteção da saúde pública.

(31) Observa-se que, por princípio constitucional (art. 62), a edição de medida provisória se justifica em caso de relevância e urgência de interesse público. 
nal", a "livre concorrência", a "erradicação da pobreza, da marginalização e da redução das desigualdades sociais e regionais" (CF, arts. $1^{\circ}$, I, IV, $3^{\circ}$, I, III,

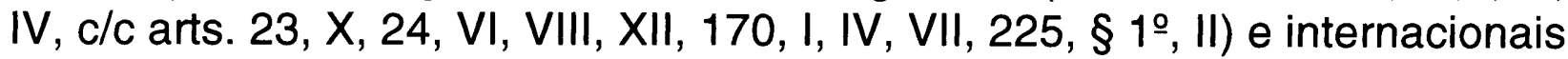
(Convenção sobre a Diversidade Biológica, arts. 3, 16, incisos 1 a 5), visando a preservar a diversidade e a integridade do patrimônio genético do País, bem como a promover o bem de todos.

6. A revisão redacional das normas dos $\S \S 1^{\circ}$ e $2^{\circ}$ do art. $8^{\circ}$ da Lei $n$. 8.974, de 5.1.1995, para fins de alteração com a substituição de normas sobre a ampla e temerária competência da CTNBio para emitir parecer prévio conclusivo (já com ilegais autorizações) referente à importação de produtos contendo OGMs, por outros dispositivos rigorosos e compatíveis com os princípios constitucionais e legais da prudência, perícia ou eficiência, da legalidade, impessoalidade, moralidade ou probidade, publicidade, sem dispensar os pareceres técnicos de outros países sobre OGMs, com a exigência de obrigatórios rótulos e transparentes informações de OGMs ou derivados de OGMs, de forma preventiva em defesa dos direitos do consumidor, do interesse público, do meio ambiente saudável ou ecologicamente equilibrado, da saúde pública e dos interesses do próprio País (CF, arts. 5으. II, XXXII, XXXIII, XXXIV, “a”, 24, VI, VIII, XII, 37, 170, V, VI, 225, § 1으, II, IV, V, VI, VII; Lei n. 6.938, de 31.8.1981, arts. $2^{\circ}, \mathrm{X}, 4^{\circ}, \mathrm{V}, 9^{\circ}$, VII, XI; Lei n. 8.078, de 11.9.1990, arts. $\left.6^{\circ}, 7^{\circ}, 9^{\circ}\right)$.

7. A revisão redacional das normas do art. $1^{\circ}-\mathrm{B}, \mathrm{I}$ a $\mathrm{V}, \S \S 1^{\circ}$ a $6^{\circ} \mathrm{da}$ Medida Provisória n. 2.191-8, de 26.7.2001 (MP revogada n. 2.137-6, de 21.6.2001), para fins de complementação da composição da CTNBio com a introdução de especialistas da Ciência do Direito de "notório saber jurídico", para trabalho conjunto com os demais "especialistas de notório saber científico e técnico" indispensável à conciliação de interesses diversos sobre OGMs, com a rigorosa observância dos princípios da prevenção de danos ambientais e da conciliação do desenvolvimento socioeconômico com a preservação ambiental, de forma compatível com os princípios constitucionais e legais vigentes, em defesa e preservação do meio ambiente, da saúde pública e da vida (CF, arts. 5인, IIXXII, XXXIII, 24, VI, VIII, XII, 37, 127 a

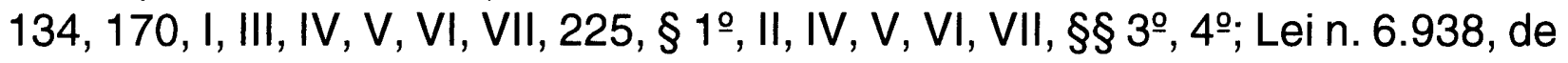
31.8.1981; Lei n. 8.078, de 11.9.1990).

8. A reabertura de novos debates, junto ao Congresso Nacional e ao Poder Executivo, tanto para os fins de apreciação e contribuições ajustáveis a Projetos de Lei sobre GMs, rotulagens de alimentos ou produtos contendo OGMs e pedido de moratória em tramitação perante o Congresso Nacional, como para os fins de reapreciação e restabelecimento das normas vetadas do art. 57 do Projeto de Lei n. 1.164/91 (transformado na Lei n. 9.605, de 12.2.1998), que definem como crime importar ou comercializar agrotóxicos ou produtos perigosos ao meio ambiente e à saúde pública de uso proibido em seu país de origem, dentre outras oportunas sugestões relacionadas 
com as medidas preventivas e a plena certeza científica ou a total convicção da verdade demonstrada por inequívocas normas legais vinculadoras de prudentes condutas, de provas ou razões lícitas, em prol da proteção, da recuperação, da melhoria e da preservação da sadia qualidade ambiental propícia à vida, à saúde pública, à liberdade, à igualdade, à segurança, à defesa dos direitos do consumidor e da coletividade, enfim, ao bem-estar das presentes e futuras gerações. 